


\title{
Robert Lowth, PARAllelism, AND Biblical Poetry
}

\author{
F. W. DOBBS-ALLSOPP \\ Princeton Theological SEMINARY
}

George Gregory opens his “Translator's Preface” to Robert Lowth's Lectures on the Sacred Poetry of the Hebrews with the following statement: "It may not be improper to apprize the public, that although the following Lectures be entitled Lectures on the Hebrew Poetry, their utility is by no means confined to that single object. They embrace all THE GREAT PRINCIPLES OF GENERAL CRITICISM."1 Recent scholarship on Lowth has been intent on reclaiming Gregory's perspective, believing that Lowth's broader intellectual impact beyond the study of biblical poetry has been too little appreciated. ${ }^{2}$ S. Prickett is emblematic of this new accent when he

${ }^{1}$ Reprinted in Robert Lowth (1710-1787): The Major Works, ed. D. A. Reibel, 2 vols. (London: Routledge, 1995), 1:v. Hereafter cited parenthetically in the body of the essay. Thanks to colleagues at Princeton Seminary's Old Testament Research Colloquium for reading and discussing the essay. They have helped me to sharpen many of my ideas. Special thanks to Simi Chavel, Blake Couey, Elaine James, Jeremy Schipper, Jordan Skornik, and Mark Smith, all of whom read through and commented on various versions of the essay. The essay has been immensely improved by the comments of two anonymous reviewers for JHS. I am extremely grateful for their sustained engagement with my work.

${ }^{2}$ E.g., M. H. Abrams, The Mirror and the Lamp: Romantic Theory and the Critical Tradition (Oxford: Oxford University Press, 1953), 78; M. Roston, Prophet and Poet: The Bible and the Growth of Romanticism (Evanston, IL: Northwestern University Press, 1965), esp. 133-38; S. Prickett, Words and the Word: Language, Poetics and Biblical Interpretation (Cambridge: Cambridge University Press, 1986), esp. 105-23; J. Engell, "Robert Lowth, Unacknowledged Legislator" in The Committed Word: Literature and Public Values (University Park: Penn State University Press, 1999), 119-40; J. Engell, "The Other Classic: Hebrew Shapes British and American Literature and Culture" in The Call of Classical Literature in the romantic Age, ed. K. P. Van Anglen and J. Engell (Edinburgh: Edinburgh University Press, 2017); S. Harshbarger, "Robert Lowth's Sacred Hebrew Poetry and the Oral Dimension of Romantic Rhetoric" in Rhetorical Traditions and British Romantic Literature, ed. D. H. Bialostosky and L. D. Needham (Bloomington: Indiana University Press, 1995), 199-214; I. Balfour, "Robert Lowth and the Temporality of Prophetic Rhetoric" in The Rhetoric of Romantic Prophecy 
writes of Lowth's Lectures that they "were to redefine the conception of Hebrew poetry; less obviously, but perhaps no less significantly in the long run, they were to redefine the notion of "poetry' itself." 3 And further, "The eighteenth-century rediscovery of the structure of biblical verse was not, as Lowth and his successors had imagined, just the discovery of a special case, but served to highlight a hitherto neglected quality latent in all verse, and so effectively to modify poetic theory as a whole. . . Lowth's work inaugurated a critical revolution." ${ }^{4}$ Even in studies of biblical poetry, where Lowth is still cited and discussed, he is less often read deeply. ${ }^{5}$ Indeed, one of the main casualties of the reassessment of the nature of parallelism within biblical studies during the late 1970s to early 1990s was Lowth himself. ${ }^{6}$ This is unfortunate. While aspects of Lowth's thinking about parallelism have been rightly criticized-especially his threefold categorization scheme-many of his insights remain as vital as ever. ${ }^{7}$ In what follows I offer a fresh look at Lowth's idea of parallelism, situating it in particular in light of more contemporary understandings of the phenomenon (as manifested in biblical poetry). The first section of the essay focuses on Lowth's general description of parallelism, a topic, surprisingly, that has not received close scrutiny by scholars. In the middle section I take up Lowth's (in)famous threefold schema for classifying the main kinds of parallelism. And in the final section, I treat aspects of orality and rhythm as they bear on an understanding of parallelism in biblical poetry. These latter phenomena, too, are aspects of how parallelism means rooted ultimately in Lowth's thinking. Mine is a close and patient reading of Lowth and his ideas about

(Stanford: Stanford University Press, 2002), 55-81; J. Fox, Explorations in Semantic Parallelism (Canberra: Australian National University Press, 2014), esp. 20-22, 42-48.

3 Prickett, Words, 41.

4 Prickett, Words, 119.

5 Notable exceptions include J. L. Kugel, The Idea of Biblical Poetry: Parallelism and Its History (Baltimore: Johns Hopkins University Press, 1981); J. B. Couey, Reading the Poetry of First Isaiah: The Most Perfect Model of the Prophetic Poetry (Oxford: Oxford University Press, 2015); J. E. Skornik, "Between the Study of Religion and Literary Analysis: Robert Lowth on the Species of Prophetic Poetry," Journal of Religion 99 (2019): 492-528.

${ }^{6}$ Cf. R. Alter, The Art of Biblical Poetry (New York: Basic Books, 1985), 3-4, 204. Some contemporary scholars even advocate overturning Lowth's ideas altogether: e.g., R. D. Holmstedt, "Hebrew Poetry and the Appositive Style: Parallelism, Requiescat in pacem," VT (2019): 1-32; E. Grosser, "What Symmetry Can Do that Parallelism Can't: Line Perception and Poetic Effects in the Song of Deborah (Judges 5:2-31)," VT 71 (2021): 175-204.

7 Though parallelism is the best-known feature of (much) biblical poetry, and largely because of Lowth's ideas, Lowth's thinking about biblical poetry is much more encompassing than this single phenomenon. Indeed, one motivation of my On Biblical Poetry (New York: Oxford University Press, 2015) was to adopt this larger Lowthian pose and to think through biblical poetry beyond the parameter of parallelism (see esp. 3-13). 
parallelism with an eye to the English divine's broader significance as a thinker. Lowth's ideas, though most closely curated and scrutinized by biblical scholars, have a wide intellectual heritage across multiple disciplines and paradigms of knowledge that requires constant reconsideration as biblical scholarship continues to reflect on and refine these ideas. One of the chief legacies of this Lowthian heritage is this wider critical purview. ${ }^{8}$

\section{LOWTH's GENERAL DESCRIPTION OF PARALlELISM}

Phenomenologically, and at its broadest, parallelism is centrally concerned with correspondence, "the quality or character of being ... analogous," "correspondence or similarity between two or more things" (OED, meanings 1 and 2), and its principal mode of manifestation (especially in the verbal arts) is through iteration or recurrence, a pattern of matching. ${ }^{9}$ As applied to prosody, the OED glosses parallelism as "correspondence, in sense or construction, of successive clauses or passages" (meaning 3). Lowth was the first to use the term with this sense, and specifically in his study of biblical Hebrew poetry (viz. parallelismus membrorum "parallelism of the clauses"; cf. OED). ${ }^{10}$ His analysis divides into two main parts: a gen-

\footnotetext{
${ }^{8}$ One of the areas in which Lowth's ideas about parallelism have been very influential is in the comparative study of traditional verbal art (e.g., Fox, Semantic Parallelism, 22). And while the robust nature of the study of parallelism by biblical scholars has been well appreciated, the critique is that "the extensive and erudite study of Biblical parallelism remains largely a self-referencing field and only rarely draws upon, or contributes to, a wider global discussion" (Fox, Semantic Parallelism, 42).

${ }^{9}$ See esp. P. Zumthor, Oral Poetry: An Introduction (Minneapolis: University of Minnesota Press, 1990), 111. Relatedly, N. Fabb describes the general phenomenon of parallelism in this way: "similarity between two or more stretches of text. Parallelism is a type of repetition like rhyme and alliteration, but holds over stretches of text like metre" "Parallelism" in What is Poetry? Language and Memory in the Poetry of the World [Cambridge: Cambridge University Press, 2015], 140).

${ }^{10}$ It is sometimes said that Lowth "invented" the term parallelism (e.g., D. A. Reibel, "Introduction" in De Sacra Poesia Hebraeorum Praelectiones Academicae Oxonii Habitae, $3^{\mathrm{d}}$ ed. [London: Clarendon, 1775 (1753)]; reprinted in Reibel's Robert Lowth (1710-1787): The Major Works, xiii-hereafter references to the Praelectiones [in this edition] are cited parenthetically in the body of the essay). But this is not quite correct. His application of the term to an analysis of prosody is original (so $O E D$ ), as perhaps is his technical understanding of parallelismus membrorum (see A. Baker, "Parallelism: England's Contribution to Biblical Studies," CBQ 35 (1973): 429-40, esp. 429_ 30; cf. Kugel, Idea, 12). The general idea of parallelism was well known in antiquity (esp. H. Lausberg, Elemente der literarischen Rhetorik [München: Hueber, 1967], esp. \$337; F. Rehkopf, “Der 'Parallelismus' im NT: Versuch einer Sprachregelung," ZNW 71 [1980]: 46-57, esp. 55) and the phrase parallelismus membrorum itself is a slight adaptation (abbreviation) of Lowth's original language: aequalitate, ac similitudine quadam, sive parallelismo, membrorum cuiusque periodi "a certain equality and similarity, or parallelism, of the mem-
} 
eral description and a threefold categorization scheme. His fullest general descriptions of parallelism are given in several places, three times in his Lectures on the Sacred Poetry of the Hebrews (1:68-69, $100 ; 2: 34)$ and once in the Preliminary Dissertation to his translation of and philological commentary on Isaiah. ${ }^{11}$ The first is the most general and appears early in Lectures, in Lecture III (on the topic of meter):

In the Hebrew poetry, as I before remarked, there may be observed a certain conformation of the sentences, the nature of which is, that a complete sense is almost equally infused into every component part, and that every member constitutes an entire verse. So that as the poems divide themselves in a manner spontaneously into periods, for the most part equal; so the periods themselves are divided into verses, most commonly couplets, though frequently of greater length. This is chiefly observable in those passages which frequently occur in the Hebrew poetry, in which they treat one subject in many different ways, and dwell upon the same sentiment; when they express the same thing in different words, or different things in a similar form of words; when equals refer to equals, and opposites to opposites: and since this artifice of composition seldom fails to produce even in prose an agreeable and measured cadence, we can scarcely doubt that it must have imparted to their poetry, were we masters of the versification, an exquisite degree of beauty and grace. (Lectures, 1:68-69)

One of Lowth's surpassing achievements was to evolve a way of talking about biblical poetry (and its prosody), precise and detailed, to be sure, but also composed with "elegance" and "infectious" in its admiration of the subject matter. ${ }^{12}$ The term "parallelism" will be

bers of each period" (Praelectiones, 242; cf. Rehkopf, "Der 'Parallelismus' im NT," 48) _ "parallelism" here is in apposition to Lowth's other descriptors. The abbreviated (and delimited) phrasing, parallelismus membrorum, appears at least as early as J. D. Michaelis's notes on Lowth's Praelectiones (in Roberti Lowth pralectiones de sacra poesia Hebraorum notc et epimetra. Ex Goettingensi editione pralectionum [Oxonii: E typographeo Clarendoniano, 1763], 99, cf. 12these notes date to 1758-61 and were a part of Michaelis's own edition of the Praelectiones [R. Lowth, De sacra poesia Hebraeorum; praelectiones academicae Oxonii habitae: subjicitur metricae Harianae brevis confutatio: et oratio Crewiana. Notas et epimetra adiecit, Ioannes David Michaelis, 2 vols. (Goettingae: Sumtibus Pockwizii et Barmeieri, 1758-61)]; Lowth simply republished these notes in a second volume attached to his own second edition of the Praelectiones [see R. Smend, "Lowth in Germany" in "The Unconquered Land" and Other Old Testament Essays, ed. E. Ball and M. Barker, trans. M. Kohl (London: Routledge, 2013), 194-214, at 201-202]).

11 Isaiah: A New Translation with a Preliminary Dissertation (London: J. Nichols, 1778; reprinted in Reibel, Major Works), x-xi (hereafter cited parenthetically in the body of the essay).

${ }^{12}$ M. Roston, Prophet and Poet: The Bible and the Growth of Romanticism (Evans- 
used only later in the Lectures (especially in Lecture XIX). Here, however, Lowth offers a first attempt to circumscribe the phenomenon, drawing especially on concepts from classical and neoclassical rhetoric (e.g., periodus, membrum)..$^{13}$ The first thing to notice is that Lowth directs his attention to the individual verse or line (the latter is the English term he will begin to use in his Preliminary Dissertation) and to the interlinear relations of immediately contiguous lines- "a certain conformation of the sentences." 14 The verse line in biblical poetry, Lowth observes, is typically composed of a part of a sentence or a clause, what he calls a "member": 15 "every member constitutes an entire verse." These clauses are mostly end-stopped: "a complete sense is almost equally infused into every component part"; i.e., line breaks occur at major clausal, phrasal, or sentential junctures. The poems divide into "periods" or sentences, ${ }^{16}$ "for the most part

ton, IL: Northwestern University Press, 1965), esp. 72; D. B. Morris, Religious Sublime: Christian Poetry and Critical Tradition in 18th-Century England (Lexington: University of Kentucky Press, 1972), 160-61; Kugel, Idea, 12, 57; D. Norton, A History of the English Bible as Literature (Cambridge: Cambridge University Press, 2004), 220.

${ }^{13}$ Lowth acknowledges his dependence on rhetorical categories such as "period" and "member" that grammarians had adapted for describing punctuation and the "constructive parts" of simple and compound sentences. See Lowth's anonymously published A Short Introduction to the Grammar of English, 2d corrected ed. (London, 1763; reprinted in Major Works), 171. As I note below Lowth is not averse to bending and blurring some of the rhetorical categories he inherits from classical antiquity, especially as his subject matter ultimately is not grammar in the Lectures and Isaiah but poetry.

14 This is one of Lowth's crucial perceptions about Hebrew verse, which, as M. O'Connor stresses, remains "unquestioned and unquestionable" (Hebrew Verse Structure [Winona Lake: Eisenbrauns, 1980], 32; cf. "Parallelism" in The New Encyclopedia of Poetry and Poetic [=NPEPP; eds. A. Preminger and T. V. F. Brogan; Princeton: Princeton University Press, 1993], 878; E. L. Greenstein, “Aspects of Biblical Poetry," Jewish Book. Annual 44 [1986-87], 33-42, at 42).

15 The English term "member" (from Lat. membrum (= Gk. koton) in its now rare sense signifying "a division or clause of a sentence" $(O E D)$, see Baker, "Parallelism," 430; M. B. Parkes, Pause and Effect: An Introduction to the History of Punctuation in the West [Aldershot: Scholar, 1992], 305); Kugel, Idea, 2-3, n. 4 (emphasizing how "grievously" Lowth's terminology has been misunderstood by later readers). For the classical understanding of membrum/colon (not a free-standing clause but a clause-usually brief and complete but does not express the entire thought—within a complex sentence or periodos), see esp. Aristotle, Rhet. 1409b, 3.9.5-7; Rhet. Her. 4.19. By the time of the Short Introduction Lowth conceptualizes the "member" as a clausal sub-part of any sentence, simple or compound (see below), which strictly speaking is opposed to classical usage.

${ }^{16}$ Lat. periodus (= Gk. periodos) in classical rhetoric designates a complex sentence (see E. Norden, Die antike Kunstprosa vom VI. Jabrhundert v. Chr. bis in die Zeit der Renaissance [Leipzig: B. G. Teubner, 1898], 1, 36-37, 48-49), and as such does not completely overlap with Lat. sententia "sentence." Alt- 
equal," 17 which "are divided into verses" (composed of clauses), "most commonly couplets" but also triplets and larger groupings. This "conformation of the sentences," Lowth emphasizes later in Lecture IV, is "wholly poetical" (Lectures, 1:99). For Lowth, there is "so strict an analogy between the structure of the sentences and the versification that when the former chances to be confused or obscured, it is scarcely possible to form a conjecture concerning the division of the lines or verses" (Lectures, 1:99).

This fixation on the site of parallelism, the line and what takes place between lines, especially within couplets (and triplets), becomes clearer in Lowth's succeeding statements. For example, in Lecture IV he emphasizes the rough equality of line-length and the prominence of couplets: "they dispose the corresponding sentences in regular distichs adapted to each other, and of an equal length, in which, for the most part, things answer to things, and words to words" (Lectures, 1:100). This is close to Lowth's better known phrasing from Lecture XIX: "a certain equality, resemblance, or parallelism[,] between the members of each period; so that in two lines (or members of the same period), things for the most part shall answer to things, and words to words" (Lectures, 2:34). Gregory even clarifies further for the English reader by adding "two lines," which is not in Lowth's original Latin; indeed, "so that in two lines (or members of the same period)" is a reworked and glossed version of the Latin original, in duobus ... membris (literally, "such that in the two members"; cf. Praelectiones, 242). Gregory here is building on Lowth's own English from the Preliminary Dissertation of 1778: "the correspondence of one Verse, or Line, with another, I call Parallelism" (Isaiah, $\mathrm{x}) .{ }^{18}$ Just before this celebrated definition of parallelism is perhaps one of Lowth's clearest descriptions of the relationship between "the composition of the Verses and the composition of the Sentences": "generally Periods coincide with Stanzas, Members with Verses, and Pauses of the one with Pauses of the other" (Isaiah, x). This English formulation is anticipated in a passing comment from a decade ear-

hough, again, Lowth in the Short Introduction blurs this distinction, viz. "the Period is the whole Sentence". (see below). In Lowth's explications of specific examples in Lectures and Isaiah, he appears generally to use periodus/"period" to identify what he takes to be complex sentences.

${ }_{17}$ The Latin term conformatio, which features in Lowth's phrase "conformation of the sentences," literally means "a symmetrical forming or fashioning” (Murray Chambers Latin-English Dictionary). Herder, too, picks up on Lowth's stress on symmetry in his gloss of "parallelism" as "a symmetry of lines" (as cited in Smend, "Lowth in Germany," 207). For a recent treatment of the interlineal dynamics of symmetry within a cognitive poetics framework, see Grosser, "What Symmetry Can Do"- - one need not cast aside the idea of parallelism in order to appreciate insights from Grosser's analysis.

18 Gregory references the later Isaiah at several points in the Lectures, including Lowth's revised description of parallelism (2:32, n. 10; cf. 1:xiv and 2:59). 
lier: "the most apparent and general Characteristic of the Hebrew Poetry is its being laid out into sentences nearly equal, and in some sort parallel; so that the limits of the Verses for the most part probably coincided with the pauses of the sentences." 19 The latter also emphasizes the end-stopped nature of the "verses," the poetic lines, that end (mostly) at major syntactic junctures. As with this statement, the sole mention of the "conformation of the sentences" in the Preliminary Dissertation blends the structural site of parallelism and parallelism itself: "Short, concise, with frequent pauses, and regular-intervals, divided into pairs, for the most part, of corresponding lines" (Isaiah, 1).

An example will illuminate and concretize Lowth's thinking:

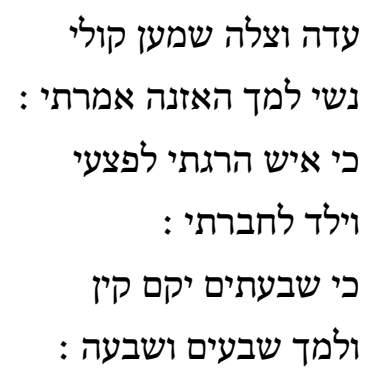

" Hadah et Sillah, audite vocem meam,

"Uxores Lamechi, auscultate eloquium meum:

"Quod virum occîdi in vulnus meum,

"Et puerum in livorem meum:

“Quia septempliciter vindicabitur Cain,

"Et Lamech septuagefies septies.

(Praelectiones, 52-53) 20

Genesis 4:23-24, which is set out in a running format in the traditional text of the Masoretic Tradition (MT; i.e., no special formatting as verse), is the first set of poetic lines Lowth treats in his Lectures. I have provided the Hebrew and Latin translation as found in Lowth's original Latin text, the Praelectiones, for a number of reasons. First, Lowth provides the Hebrew of every major example he discusses and lineates them, even when (as here in Gen 4:23-24; see Fig. 2) there are no extant specially formatted manuscripts. Lowth's arrangement of the Hebrew makes clear visually his understanding of the poetic line structure and how these lines are grouped (here as couplets). That is, the Hebrew alone as set out by Lowth provides a very concrete (and "neat") understanding of what he means by the

${ }^{19} \mathrm{R}$. Lowth, A Larger Confutation of Bishop Hare's System of Hebrew Metre, in a Letter to the Rev. Dr. Edwards: In Answer to bis Latin Epistle (London: A. Millar, 1766), 63.

${ }^{20}$ I use the Hebrew square script in these examples because Lowth does. 
"conformation of the sentences"- a strict "analogy between the structures of the sentences and the versification" (Lectures, 1:99).

Unfortunately, Gregory decides not to include the Hebrew in his translation of the Lectures so this visible component of Lowth's argument is completely occluded in translation-after 1787 most (English-language) scholars read Lowth only in translation. ${ }^{21}$ Without the lineated Hebrew of Gen 4:23-24, for example, Lowth's description becomes less visibly specific - readers do not see the Hebrew poetic lines or their groupings into couplets (which is opposed to the running format of MT). Another peculiarity of Gregory's translation is his decision not to render the "inimitable" Latin of Lowth's own scripture translations into English but instead to use English translations of other scholars; and when these are not readily available, he offers his own English renderings of the Hebrew (Lectures, 1:xii-xiv; from the "Translator's Preface"). What needs underscoring, then, is that these are not renderings of Lowth's Latin 22 and sometimes they do not reflect Lowth's thinking as precisely as they might. The rendering of Gen 4:23-24 included by Gregory in Lectures, for example, is lined out as three parallel couplets, as per Lowth's analysis (Lectures, 1:89), but he punctuates them as two sentential units (following MT), instead of the single, complex "period" as diagnosed by Lowth (viz. "the exact distribution of the period into three distichs"; Lectures, 1:89):

"Hadah and Sillah, hear my voice;

"ye wives of Lamech, hearken to my speech;

" for I have slain a man, because of my wounding;

" a young man, because of my hurt.

"If Cain shall be avenged seven times,

" certainly Lamech seventy and seven.

${ }^{21}$ In doing this Gregory is likely following Lowth's example of the Preliminary Dissertation. The same practice prevails in the excerpt of Lowth's Latin from Lecture VI in the extended book notice in the popular Monthly Review (VIII [June, 1753], 401-13); and also in the first partial translation (the first eighteen lectures) of Lowth's Praelectiones commissioned by W. Dodd, which appeared in monthly installments in the Christian's Magazine from 1767-68. Neither Roger's French translation (R. Lowth, Cours De Poésie Sacrée, trans. F. Roger [Paris: Migneret, 1813]) nor the peculiar extract of Lowth's lectures in German (R. Lowth et al., Ausqug aus D. Robert Lowth's Lord Bischofs zu London Vorlesungen Über die heilige Dichtkunst der Hebräer: mit Herders und Jones's Grundsätzen Verbunden: Ein Versuch, zur Beförderung des Bibelstudiums des Alten Testaments, und insbesondre der Propheten und Psalme [Danzig: Bey Ferdinand Troschel, 1793]) include the Hebrew.

${ }^{22}$ Gregory does say that he draws on Lowth's Isaiah for translations of Isaiah (Lectures, 1:xiv), though even this is not consistent (e.g., Isa 30:26 in Lectures, 1:129 is not from Isaiah, 77). 
(Lectures, 1:89)

For contemporary readers of Lowth in Gregory's translation the combination of rhetorically based vocabulary with meanings that are now outdated and obscure (e.g., "member" meaning clause or phrase, "period" for sentence) and of English translations of biblical examples with punctuation sometimes at odds with Lowth's explications can be confusing - and with no Hebrew provided for control purposes. ${ }^{23}$

Further, in both the Praelectiones/Lectures and Isaiah Lowth does not always explicate his examples as much as contemporary readers might wish. He places a great deal of emphasis on the "neatness" of his examples, which D. A. Reibel glosses as "transparency," where "the construction should be evident without analytical effort, and contribute to the clarity of expression." ${ }^{24}$ That is, built into the "neatness" of Lowth's argument is the expectation that his examples are chosen because of the clarity and transparency with which they illustrate whatever point is at issue. In the extended discussions of parallelism in Lecture XIX and in the Preliminary Dissertation runs of examples with spare commentary are common. Lowth even mentions "the utmost accuracy and neatness" of the numerous examples of "synonymous parallelism" in biblical poetry (Lectures, 2:35). This is to underscore the intellectual work that Lowth's examples do on their own and the dilution of this work when the Hebrew is dropped and the translations of scripture are not carefully tuned.

Lowth's linguistic sophistication has sometimes been disparaged. ${ }^{25}$ Such criticism is anachronistic and inaccurate. Lowth was writing before linguistics evolved into a modern humanistic discipline and anticipated the (re)turn to philology at the end of the eighteenth century. ${ }^{26}$ In 1762 he anonymously published Short Introduction

${ }^{23}$ C. E. Stowe severely criticizes Gregory's decision to substitute English translations for Lowth's own Latin renderings of scripture: "It was a great error of the translator, and one into which he was led, it would seem, by the judgement of others rather than his own, to substitute English translations of Scripture, drawing from various sources and of very unequal merit, for the inimitable Latin versions of Lowth" (R. Lowth, Lectures on the Sacred Poetry of the Hebrews, New Edition with Notes, ed. C. E. Stowe, trans. G. Gregory [Andover: Codman, 1829], xii-xiii). Stowe restores Lowth's Latin (p. xiv) without English renderings (and still minus the Hebrew of Lowth's Praelectiones).

24 "Introduction" in Isaiah, xxxi.

${ }^{25}$ E.g., A. Berlin, The Dynamics of Biblical Parallelism (Bloomington: Indiana University Press, 1985), 2; S. I. S. Goh, The Basics of Hebrew Poetry: Theory and Practice (Eugene: Cascade Books, 2017), 25. Lowth was a capable enough Hebraist, though he did not control other Semitic languages like Michaelis (see Smend on Michaelis and Lowth, "Lowth in Germany," 197204).

26 The latter is conveniently marked in biblical studies by the appearance of J. G. Eichhorn's Einleitung in das Alte Testament, 3d ed., 3 vols. (Leipzig: Weidmann, 1803 [1780-83]). Eichhorn appreciated Lowth's im- 
to English Grammar that was reprinted in many editions and was influential long after Lowth's death. ${ }^{27}$ Reibel argues that the Short Introduction is indispensable to the more sophisticated discussion of parallelism in the Preliminary Dissertation: "without this grammatical insight and acumen [gained from writing the Short Introduction], he would have not been able to develop his argument in anything like the convincing detail that is to be found" in the Preliminary Dissertation. ${ }^{28}$ The most innovative aspect of Lowth's Short Introduction was his extensive and unparalleled (for the time) treatment of syntax, comprising a full third of the book. ${ }^{29}$ The Praelectiones predates the Short Introduction by more than a decade, yet Lowth's careful syntactic descriptions of "the conformation of the sentences" as the site of parallelistic play in biblical poetry anticipate his enhanced attention to syntax in both the Short Introduction and the Preliminary Dissertation. For example, his use of "member" and "period" is generally consistent with the definitions he supplies in the Short Introduction: "The Period is the whole Sentence, complete in itself, wanting nothing to make a full and perfect sense, and not connected in construction with a subsequent Sentence"; and "The Colon, or Member, is a chief constructive part, or greater division, of a Sentence." 30 And here is his discussion of "Simple" and "Compound" sentences: "As sentences themselves are divided into Simple and Compounded, so the members of sentences may be divided likewise into Simple and Compounded: for whole sentences, whether Simple or Compounded, may become members of other Sentences by means of some additional connection." 31 Though Lowth emphasizes seman-

portance: "let no one forget. . .that we have become what we are, at least in part, through his contribution" (as cited in Smend, "Lowth in Germany," 214).

${ }^{27}$ Reibel, "Introduction" in Short Introduction, v. It was apparently used at Harvard into the mid-nineteenth century; see Prickett, Word and the Words, 105.

28 "Introduction" in Isaiah, x-xi.

${ }^{29}$ Reibel, "Introduction" in Short Introduction, esp. v-vii.

30 Short Introduction, 170. These represent slight modifications of the classical understanding of "member" and "period": "member" has been generalized as a designation for a sub-part (clause) of any kind of sentence and "period" and "sentence" are coextensive. More recently, Fabb has reappropriated Lowth's term "member" (now in its usual modern English sense) to designate the stretch of text that distinguishes poetry (the line) and is a constitutive part of a parallelistic grouping- "each stretch of text, called a parallel member" and "normally" a member (or line) is "small enough to fit into working memory" (What is Poetry? 140).

31 Short Introduction, 178. Throughout his discussion of syntax, Lowth often foregrounds the issue of word order, given that English word order is much more restrictive with its eroded inflectional morphology (cf. Reibel, "Introduction" in Short Introduction). Word order in biblical Hebrew is similarly restrictive, meaning that Lowth's thinking through of English grammar in fact would have served his grammatical understanding of Hebrew very well just as Reibel contends. 
tics in his description of parallelism (especially in his threefold categorization of the different kinds of parallelisms), there is no denying that the line and its grouping is the principal site of poetic parallelism in Lowth's analysis and that these structural levels are described syntactically. Following Lowth's own lead especially in the Preliminary Dissertation - "the correspondence of one Verse, or Line, with another, I call Parallelism"-most contemporary biblical scholars speak (and write) loosely of "parallelism" in biblical poetry. ${ }^{32}$ However, it is clear from all of Lowth's discussions that what is chiefly in view for him is parallelism as between member lines, where the line is the fulcrum of singularity upon which parallelism acts for its play. ${ }^{33}$ There was a time when biblical scholars would use the phrase parallelismus membrorum as a technical term for the phenomenon in view. ${ }^{34}$ And the usage has merit precisely because it reifies helpfully the structural site of parallelism, namely, the line and how the line is grouped- "the correspondence of one Verse, or Line, with another." 35

The symmetrical shaping of the sentences into roughly balanced poetic lines that Lowth takes such pains to delineate, if closely aligned with parallelism, ultimately is separable from parallelism as well. ${ }^{36}$ This "conformation of the sentences," argues Lowth, "is chiefly observable in those passages" in which the correspondence

\footnotetext{
32 Also already in the Praelectiones (506): Sententiarum Parallelismus "parallelism of sentences."

33 As Fabb in particular emphasizes, "lineation is independent of parallelism" (What is Poetry? 146). Gerard Manley Hopkins distinguishes this tight focus on the parallelism of lines as "the technical so-called parallelisms of Hebrew poetry" and contrasts their narrower purview to his more expansive notion of "continuous parallelism," which for Hopkins is "the structure of poetry": "all artifice, reduces itself to the principle of parallelism" ("Poetic Diction" in The Collected Works of Gerard Manley Hopkins, vol. 4: Oxford Essays and Notes, ed. L. Higgins [Oxford: Oxford University Press, 2006], 120; cf. 161, 162). R. Jakobson follows Hopkins' lead and considers parallelism the master trope of poetry (e.g., "Closing Statement: Linguistics and Poetics," in Style in Language, ed. T. A. Sebeok [New York: John Wiley \& Sons, 1960], 350-77, esp. 368, 374). A. Berlin, among contemporary biblical scholars, has argued to rethink Lowth's ideas about parallelism in this more far-reaching sensibility (Dynamics).

${ }^{34}$ E.g., F. Hölscher, Das Buch Hiob im „Parallelismus membrorum, “ ̈̈bersetzt aus dem Hebräischen (Osnabrück: Rackhorst, 1839); Driver, Introduction, 362; O'Connor, Hebrew Verse Structure, 32. Kugel uses this more precise phrasing throughout Idea.

${ }^{35}$ Cf. Petersen and Richards, Interpreting Hebrew Poetry, 22. In any such contemporary reappropriation of this terminology, membrorum "member" may be allowed to refract its classical and Lowthian sensibilities (viz. clause in a complex sentence, any non-free standing clause), while also permitting a more contemporary gloss following Fabb (viz. the member as the lineal constituent that is combined into parallel patterns; What is Poetry? esp. 14243).

${ }^{36}$ Lowth conflates the two in Lectures, 2:53.
} 
between lines he calls parallelism obtains, namely, where "they treat one subject in many different ways, and dwell upon the same sentiment; when they express the same thing in different words, or different things in a similar form of words; when equals refer to equals, and opposites to opposites" (Lectures, 1:68-69). Here in Lowth's first description of the phenomenon, parallelism is identified primarily as a means of recognizing the "conformation of the sentences." From the latter it follows that parallelism helps to make line structure visible- "the limits of the Verses for the most part probably coincided with the pauses of the sentences." 37 It is what Lowth depends on most heavily when delineating line boundaries in biblical poems inscribed in running formats (as in the Latter Prophets). Indeed, parallelism is a very common oral technique for end-fixing. ${ }^{38}$ Since Lowth, Western biblical scholarship has been mostly accustomed to "seeing" parallelism on the "silent" page of a biblical manuscript. But parallelism itself is engineered for efficient aural uptake and remembrance - and the biblical poetic tradition, of course, is rooted in orality and aurality. ${ }^{39}$ It is the voiced (spoken, sung) word and groups of voiced words that are acoustically shaped into iterative patterns by parallelism. ${ }^{40}$ Like the silence of a pause, parallelism marks the end of a line only belatedly, retrospectively. ${ }^{41}$ The cues

${ }^{37}$ Lowth, Larger Confutation, 63; cf. Lectures, 1:344. See Kugel, Idea, 27677; Couey, Poetry of First Isaiah, 27-36. Hopkins observes what he describes as this "well-known" phenomenon: "Hebrew poetry, you know, is structurally only distinguished from prose by its being paired off in parallelisms, subdivided of course often into lower parallelisms" ("A Platonic Dialogue" in Higgins, Collected Works, 159).

38 O'Connor, "Parallelism," 878: "p[arallelism] plays a role in structuring the line." Cf. J. Sherzer, "Poetic Structuring of Kuna Discourse: The Line" in Native American Discourse, ed. J. Sherzer and A. C. Woodbury (Cambridge: Cambridge University Press, 1987), 371-90; D. Tedlock, "Toward an Oral Poetics," NLH 8 (1977): 507-8; idem, "Hearing a Voice in an Ancient Text: Quiche Maya Poetics in Performance," in Sherzer and Woodbury, Native American Discourse, 146 and n. 4; W. Bright, "With One Lip, with Two Lips': Parallelism in Nahuatl," Language 66 (1990): 437-52, esp. 437-438; J. M. Foley, "Word-Power, Performance, and Tradition," Journal of American Folklore 105 (1992): 275-301, esp. 286, 296, n. 16; T. V. F. Brogan, "Line" in NPEPP, 694-95; OED, s.v. "parallelism," esp. definition no. 3.

${ }^{39}$ For details and literature, see F. W. Dobbs-Allsopp, "An Informing Orality: Biblical Poetic Style," in On Biblical Poetry, 233-325. More recently, see broadly, Fox, Semantic Parallelism; N. Fabb, "Poetic Parallelism and Working Memory," Oral Tradition 31 (2017): 355-72.

${ }^{40}$ For an explication of how echo, repetition, formulas, parallelism, and the like enable oral poetic communication, see the discussion in E. A. Havelock, Preface to Plato (Cambridge: Harvard University Press, 1963), esp. chs. 8-9.

${ }^{41}$ C. B. Paternack also appreciates how parallelism "prompts a [vocalizing] reader or listener to recognize starting or stopping points within the linguistic sequence" (The Textuality of Old English Poetry [Cambridge: Cambridge University Press, 1995], 131). 
come after the line actually ends in the auditor's recognition of iteration, the engine of parallelism and the sign that a new line is underway. The unit iterated is the line, its shape emerging as the matching syntactic frames of the adjacent lines are set in equivalence. ${ }^{42}$ Lines of biblical verse are normally small enough to permit the whole couplet to fit into working memory, which facilitates this kind of processing. The parallel shapes and meanings ease memory's burden. ${ }^{43}$ Isaiah 11:3 is a typical example:

$$
\begin{aligned}
& \text { weไö-lëmar'è-(b) 'ênaỳw yišpột } \\
& \text { weไo-lëmišma' 'oznāyw yokiah } \\
& \text { Conj-Neg-PP + V } \\
& \text { Conj-Neg-PP + V } \\
& \text { and-not-according-to-the-vision-of his-eyes will-he-judge } \\
& \text { and-not-according-to-the-hearing-of his-ears will-he-decide }
\end{aligned}
$$

The matching syntactic frames here are most exact. The onset of the frame (Conj-Neg-PP), repeated from the initial line, in weไo-lémišma 'oznaym of the second line throws the ending of that first line after yispot $t$ into relief. And concomitantly, recognition of the reiterated frame as a whole enhances the force of closure that accompanies yokiah in the second line, which itself mimes the line-ending yis pot of the first line.

The OED's emphasis on correspondence in its definition of parallelism- "correspondence, in sense or construction, of successive clauses or passages" (meaning 3)-is essentially a gloss on Lowth's own understanding of the concept. This is most obvious in the definition given in the Preliminary Dissertation, viz. "the correspondence of one Verse, or Line, with another" (Isaiah, x), which is the first authority cited by the OED. ${ }^{44}$ What this correspondence entails is variously described by Lowth: the expression of "the same thing in different words, or different things in a similar form of words; when equals refer to equals, and opposites to opposites" (Lectures, 1:68-69); "they repeat, they vary, they amplify the same sentiment" (Lectures, 1:100); "consists chiefly in a certain equality, resemblance, or parallelism[,] between the members of each period; so that. . things for the most part shall answer to things, and words to words, as if fitted to each other by a kind of rule or measure" (Lectures, 2:34); or "when a proposition is delivered, and a second is Subjoined to it, or drawn under it, equivalent, or contrasted with it, in Sense or Similar to it in the form of Grammatical Construction" (Isaiah, $\mathrm{x}-\mathrm{xi}$ ). These several descriptions always entail multiple de-

\footnotetext{
${ }^{42}$ Cf. O’Connor, "Parallelism," 877.

${ }^{43}$ For details and supporting literature, see esp. Fabb, "Parallelism and Working Memory."

${ }^{44}$ Berlin emphasizes (Dynamics, 2) correspondence at the core of parallelism and credits it as one of Lowth's enduring insights.
} 
scriptors (e.g., repeat, vary, amplify; subjoined, drawn under, equivalent, contrasted) and often include qualifiers (e.g., chiefly, for the most part). One does not get the impression that Lowth is intending to tightly circumscribe parallelism with any one set of terms but is, rather, gesturing to a range of observed correspondences- "they treat one subject in many different ways, and dwell on the same sentiment" (Lectures, 1:68). Indeed, he stresses this fact in Lecture XIX immediately following his general description of parallelism: "this parallelism has much variety and many gradations; it is sometimes more accurate and manifest, sometimes more vague and obscure" (Lectures, 2:35; cf. 39). One unfortunate consequence of how Lowth goes on to categorize parallelism is to limit how these correspondences would be conceptualized by later generations of scholars. But the impulse of his more general description of the trope (or "ornament" as Lowth calls it in Lecture IV; Lectures, 1:100) ${ }^{45}$ is an expansive understanding of parallelism. ${ }^{46}$

Another remarkable feature of Lowth's general description of parallelism is that it foregrounds syntax as well as semantics: "when they express the same thing in different words, or different things in a similar form of words." This emphasis remains consistent in his diagnosis of parallelism. Lowth may be at his most eloquent in Lecture IV, where he remarks about the runs of parallel lines that "they express the same or a similar, and often a contrary sentiment in nearly the same form of words" (Lectures, 1:100). Yet it is in the Preliminary Dissertation where he is most explicit and exact (post-Short Introduction), viz. "in Sense or Similar to it in the form of Grammatical Construction" (Isaiah, $\mathrm{x}-\mathrm{xi}$ ). I underscore this emphasis on semantics and syntax- "the Form of Grammatical Construction"-because Lowth goes on to organize his (in)famous threefold division of the "species" of parallelism (mostly) according to semantic effects-syn-

${ }^{45}$ Fabb describes parallelism as an "added form," by which he means a form that does not occur systematically in ordinary language and that appears predictably in a poetic text (What is Poetry? 17). Strict predictability, however, is not requited for formal patterns to signify. What is required to prompt auditorial expectations (probabilistically) is a sufficient amount of recurrence within apprehensible "limits of variability" (B. H. Smith, Poetic Closure: A Study of How Poems End [Chicago: University of Chicago Press, 1968], esp. 85-99; cf. 156-68).

46 Interestingly, Hopkins, writing a century later and whose notion of parallelism is intentionally expansive, offers ("speaking roughly") a general characterization of parallelism that broadly echoes the several from Lowth: Now the force of this recurrence is to be beget a recurrence or parallelism answering to it in the words or thought and, speaking roughly and rather for the tendency than the invariable result, the more marked parallelism in structure whether of elaboration or of emphasis begets more marked parallelism in the words and sense. And moreover, parallelism in expression tends to beget or passes into parallelism in thought ("Poetic Diction" in Higgins, Collected Works, 120-21).

Like Lowth, Hopkins also emphasizes the gestural quality of his observation, viz. "rather for the tendency than the invariable result." 
onymous, antithetical, and synthetic ${ }^{47}$ parallelism. It is this threefold schema that allowed Lowth's theory of parallelism to prevail for more than two centuries, and it is this same threefold schema that was the chief provocation for biblical scholars' critiques of the Lowthian paradigm beginning in the late 1970s. Stephen A. Geller, for example, begins his study by expressing dissatisfaction "with the treatment of parallelism in biblical literature," which up to that point was essentially the elaboration of Lowth's ideas. ${ }^{48}$ Lowth's presentation and his reception chiefly in translation led to an overemphasis on semantics. Heinrich Ewald is emblematic when already in the middle of the nineteenth century he glosses biblical poetic parallelism as gedankenrhythmus "thought-rhythm." 49 But to emphasize semantics (thought) to such a degree, especially to the occlusion of grammatical forms, is to misconstrue the nature of language art (form and meaning work together) and to distort Lowth's treatment, in which grammar (syntax) factors just as significantly as semantics. ${ }^{50}$

A typical example is Lowth's description of gapping in parallel couplets such as this one from Ps 105:20:

\section{שלח מלך ויתירהו

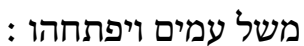

“Misit rex, et solvit eum;

"Dominator populorum, et eum liberavit.

47 Alternatively called "Constructive" (Lectures, 2:49; Isaiah, xxi), a term Lowth uses to signify syntactic elements, i.e., "the constructive parts" of a sentence, nouns, verbs, clauses, negatives, etc. Thus, the categorization scheme itself is not entirely thematized according to semantics.

48 Parallelism in Early Biblical Poetry, HSM 20 (Missoula: Scholars, 1979), 1.

49 Die Dicbter des Alten Bundes (Göttingen: Vändenhoeck und Ruprecht, 1866), 1:111; cf. T. H. Robinson, The Poetry of the Old Testament (London: Gerald Duckworth \& Co., 1947), 21.

${ }^{50}$ Reibel makes this point emphatically with respect to Lowth's analysis: "it should be pointed out that, without the pragmatic and semantic. . parallelism, the grammatical parallelism would be meaningless" " Introduction" in Praelectiones, xvi). Hopkins emphasized such holism (inclusive of meaning and grammatical form) in his understanding of parallelism (broadly inherited from Lowth and Herder); see M. R. Lichtmann, “ 'Exquisite Artifice': Parallelism in Hopkins' Poetics" in The Contemplative Poetry of Gerard Manley Hopkins (Princeton: Princeton University Press, 1989), 760. Cf. F. I. Andersen, The Sentence in Biblical Hebrew (The Hague: Mouton, 1974), 38 (parallelism must entail an equivalence "in both meaning and grammatical structure"); Greenstein, “Aspects of Biblical Poetry," esp. 34 36, 38 (on Lowth, recognizing the latter's emphasis on the "repetition of syntax and sense"); Kugel, Idea, 49, n. 127; Berlin, Dynamics, 20; S. A. Geller, "Hebrew Prosody and Poetics, Biblical" in The Princeton Encyclopedia of Poetry and Poetics (= PEPP), $4^{\text {th }}$ ed., ed. R. Greene (Princeton: Princeton University Press, 2012), loc. 33866 (Kindle edition). 
(Praelectiones, 249)

"The king sent and released him;

"The ruler of the people, and set him free.

(Lectures, 2:41)

The verb "sent" (BH שלח) in the first line is elided or gapped in the second, and yet the full sense of the second line requires the presence of the verb for its intelligibility, viz. "The ruler of the people [sent], and set him free." 51 Having already glossed synonymous parallelism generally as "when the same sentiment is repeated in different, but equivalent terms" (Lectures, 2:35), emphasizing semantics, Lowth's explication of gapping in Ps 105:20 and other parallelistic couplets like it (e.g., Isa 49:7) is all syntactic in nature: "There is frequently something wanting in the latter member, which must be repeated from the former to complete the sentence" (Lectures, 2:41).

Moreover, the role of syntax, and of word order in particular, though not always foregrounded in Lowth's exposition, is made most visible in the Praelectiones in the Hebrew that is left out of Gregory's translation in the Lectures. The "neatness" of Lowth's Hebrew examples (in particular) ${ }^{52}$ smuggles in covertly, as it were, much information that goes without explicit analytic explication. A hint of the importance of such information is provided in the first set of examples in Lowth's discussion of parallelism in the Preliminary Dissertation where, as Lowth remarks in a footnote, "the terms in English, consisting of several words, are hitherto distinguished with marks of connection; to shew, that they answer to single words in Hebrew" (Isaiah, xiii, n. 1). ${ }^{53}$ His first example, from Ps 21:1-2, exemplifies this practice:

" O-Jehovah, in-thy-strength the-king shall-rejoice;

" and-in-thy-salvation how greatly shall-he-exult!

" the-desire of-his-heart thou-hast-granted unto-him;

" and-the-request of-his-lips thou-hast-not denied.

(Isaiah, xi)

51 The reference is to the Joseph story when Pharaoh literally "sends" (from the same BH root שלח, Gen 41:14) to have Joseph released from prison. BH III נתר (piel) "to release" and BH free, loosen, open" are used in parallel also in Isa 58:6. Reibel slightly misunderstands what is being gapped in this example ("Introduction" in Praelectiones, xvi) and many recent English translations level through the gapping entirely (e.g., NRSV, NJPS).

52 Though these are often supported by Lowth's Latin translation. For example, note the fronting of "Misit" in the Latin translation to mirror the placement of שלח in the Hebrew of Ps 105:20.

53 The examples so distinguished are on pp. xi-xiii. Lowth drops this convention after these first examples. 
Lowth's explanation of the groups of English words joined with a hyphen gives visibility to the Hebrew's sparer use of words. However, the examples (such as Ps 21:1-2) show that he also takes care to replicate Hebrew word order as far as English style permits. ${ }^{54}$ Contrast, for example, the contemporary NRSV, which adjusts its translation to reflect natural English word order:

In your strength the king rejoices, O LORD,

and in your help how greatly he exults!

You have given him his heart's desire,

and have not withheld the request of his lips.

Attention to word order is part of the "neatness" of Lowth's examples that otherwise goes uncommented on by Lowth. Thus, despite the emphasis on semantic effect in Lowth's exposition generally, syntax and word order are critical to his understanding of the structural core of "parallelism of sentences."

It is the (re)turn to linguistics by modern biblical scholars some two hundred years later that was a major stimulus for reassessing the nature of parallelism in biblical poetry. With a whole panoply of new linguistic tools these scholars were able to expand and sophisticate Lowth's original diagnosis. Adele Berlin's Dynamics of Biblical Parallelism (1985) is paradigmatic as she, leveraging the work of Roman Jakobson in particular, explores the play of parallelism beyond semantics at all levels of linguistic structure, including sound elements (phonetics), grammar (morphology and syntax), and words and their meanings (lexicon and semantics). The precision of the linguistic analysis is well advanced of what Lowth could achieve and the exposition explicit where Lowth was often reticent or latent, allowing the "neatness" of his examples to stand in for explication. But in this aspect the trajectory of analysis carries forward Lowth's work. ${ }^{55}$ For example, though morphological and phonological dimensions of parallelism do not often come in for specific comment by Lowth, his awareness of these dimensions of language may be presumed on the basis of his treatment of them in his Short Introduction (and in the commentary of Isaiah) and are made visible in his examples. And sometimes he does comment on them. An example of the latter occurs in Lowth's description of "Antithetical parallelism," where he clarifies the kinds of opposition he has in mind: "This is not confined to any particular form: for sentiments are opposed to sentiments, words to words, singulars to singulars, plurals to plurals, \&c" (Lectures, 2:45). Here alone he has in view semantics ("sentiments"), lexicon ("words"), and morphology ("singulars," "plurals")—and his "\&c" makes apparent his awareness of other manifestations of linguistic "form."

\footnotetext{
${ }^{54}$ Cf. Roston, Prophet and Poet, 134-36.

55 Cf. Petersen and Richards, Interpreting Hebrew Poetry, 26.
} 
Sometimes in these more recent linguistic discussions there can be an over-emphasis on linguistics. For example, Berlin writes, "linguistics is fast becoming the prism through which poetry is viewed." 56 However, without denying the importance of linguistic knowledge to the study of any language art, poetry included, there is more to language art than can be revealed by linguistic analysis alone. In fact, this is something Lowth's Lectures teaches well, especially about biblical Hebrew poetry. ${ }^{57}$ As Engell observes, Lowth changes profoundly all definitions of poetry and alters practice permanently. He sees literature inextricably bound up with the totality of experiences of a people- a nation-over time, and as fundamentally connected with their daily practices, high and low. Thus, he establishes a new, mixed mode of criticism at once historical, cultural-we might call it anthropological, too-and aesthetic. It's the combination of Lowth's subject matter and the way he approaches it that gives his work extraordinary, if unacknowledged, power. The tendencies he establishes become so woven into the fabric of Western literature and culture that his role in creating them has nearly vanished. ${ }^{58}$

It is precisely the totality of how Lowth approached the study of biblical poetry that the field has been slow to absorb fully. The immediately succeeding generation of German Hebrew Bible scholars (Michaelis, Eichhorn, Herder), who would usher in the so-called "higher criticism" that would become central to critical biblical scholarship, well appreciated Lowth's historical and literary contributions, but showed little interest in the aesthetic side of Lowth's scholarship, ${ }^{59} \mathrm{a}$ bias in turn bequeathed to succeeding generations of biblical scholars. Linguisitc knowledge, however crucial, on Lowth's "epoch-making" teaching in Lectures, ${ }^{60}$ is but one dimension of poetic analysis among many others, including the historical-cultural, literary, and aesthetic.

Berlin ultimately moves away from Lowth's tight focus on "the conformation of the sentences" as the site of parallelism and resists his privileging of syntax and semantics, though she knows well that "grammatical and semantic parallelism generally co-occur" in biblical poetry. ${ }^{61}$ Edward L. Greenstein and Michael O'Connor more obviously carry forward Lowth's focus on parallelism in biblical poetry as a formal dimension of poetic structure preoccupied (in a large way) with lines and the interaction of lines. ${ }^{62}$ Greenstein situates the

56 Dynamics, 18.

${ }^{57}$ Cf. Dobbs-Allsopp, On Biblical Poetry, 3-13.

58 "Robert Lowth," 119-20.

59 Smend, "Lowth in Germany," 195-214.

60 The characterization is that of Prickett, Words and the Word, 41.

${ }^{61}$ Berlin, Dynamics, 22. Fabb labels this formal dimension, "lexico-syntactic parallelism" (What is Poetry? 143), which is prevalent in parallelistic poetic traditions cross-culturally.

${ }^{62}$ Greenstein and O'Connor appreciated the larger purview of parallelism qua parallelism in biblical poetry (see their broader characterization 
phenomenon of parallelism structurally at the interface of "one line of verse" with "the following line or lines" and foregrounds the "repetition of a syntactic pattern." 63 This twofold focus means to challenge the view that "whatever goes on between two lines" of biblical Hebrew verse is meaningfully denominated as parallelism. ${ }^{64}$ For O'Connor, too, "the core of a p[arallelism] is syntactic"- "the repetition of identical or similar syntactic patterns in adjacent phrases, clauses, and sentences." 65 He elaborates its inner workings (indebted to Jakobson's thinking), "when syntactic frames are set in equivalence by $\mathrm{p}$ [arallelism], the elements filling those frames are brought into alignment as well," especially at the lexical level (semantics) but potentially (all) other linguistic levels may (also) be activated. ${ }^{66}$ Greenstein, in his revision of O'Connor's entry on "Parallelism" in the newest version of The Princeton Encyclopedia of Poetry and Poetics,

noted below). In this early work (in particular) their intent is to isolate the importance of the syntactic dimension of what Lowth called the "conformation of the sentences." O'Connor in Hebrew Verse Structure even abandons the term parallelism in describing this syntactic dimension and uses "matching" instead (391-400).

63 "How Does Parallelism Mean?" in A Sense of a Text, JQRS, ed. S. A. Geller (Winona Lake: Eisenbrauns, 1983), 41-70; here 43, 44. While Lowth, too, emphasized syntax, as indicated above, Greenstein here builds more directly on I. M. Casanowicz's understanding of parallelism as "the regularly recurring juxtaposition of symmetrically constructed sentences" ("Parallelism in Hebrew Poetry" in Jenish Encyclopedia, vol. 9 [New York, 1905], 520b); cf. Greenstein, "Aspects of Biblical Poetry," 39; idem, "Direct Discourse and Parallelism" in Discourse, Dialogue, and Debate in the Bible: Essays in Honor of Frank H. Polak, ed. A Brenner-Idan (Sheffield: Sheffield Phoenix, 2014), 79-92, esp. 81 and n. 9. R. D. Holmstedt also focalizes the structural importance of the line and its interlinear relations, albeit in an effort to overthrow the Lowthian idea of parallelism ("Appositive Style," esp. 7). However, it is here, in my view, where Holmstedt is himself most Lowthian. His criticism of Lowth is mostly (mis)directed at Lowth's categorization scheme (see below) and not his general description(s) of parallelism.

${ }^{64}$ Greenstein, "How Does Parallelism Mean?" 45. Lowth's catch-all category of "synthetic parallelism" is the main inducement for such nonchalant construals of parallelism. A significant dimension of Greenstein's analysis is his appeal to deep structure with certain types of transformational rules that delete or reorder surface structure (see esp. "How Does Parallelism Mean?” 46-70). This approach remains under appreciated; see Fabb's provocative comments on Kiparsky's ideas, which also inform Greenstein's analysis (What is Poetry? 143). See Lowth's characterization of gapping: "when the Verb, or the Nominative Case of the first Sentence is to be carried on to the second" (Isaiah, xiii-xiv).

65 "Parallelism," 877-97, here 877.

66 "Parallelism," 877. Greenstein acknowledges the closeness of his thinking on this topic to that of O'Connor ("How Does Parallelism Mean?" 45, n. 14), pointing especially to the latter's Hebrew Verse Structure, 118-21; cf. O'Connor, "The Contours of Biblical Verse: An Afterword to Hebrew Verse Structure" in Hebrew Verse Structure (Winona Lake, IN: Eisenbrauns, 1997 [1980]), 640-41. 
allows that while "the repeating structure is often syntactic in nature," as prototypically in biblical Hebrew verse, "the repetition may entail other ling[uistic] components" (e.g., lexicon, morphology, rhythm). ${ }^{67}$ And most recently Robert D. Holmstedt has begun to focus more formally on the syntactic relationship between (parallel) lines. ${ }^{68}$ One of the gains, then, in the understanding of poetic parallelism in the Bible since the late 1970s is the renewed attention paid to syntax (and other levels of linguistic structure), since the tendency after Lowth in biblical scholarship on parallelism was to emphasize "semantic repetition." 69

Beyond the line and the parallel patterns that combine closely adjacent lines, there is a third dimension of formal structure revealed in Lowth's general morphology of parallelism, namely, "words [answering] to words" (Lectures, 1:100; 2:34). ${ }^{70}$ This aspect of Lowth's analysis is spelled out most precisely in the Preliminary Dissertation: "the words, or phrases, answering one to another in the corresponding Lines" is designated as "Parallel Terms" (Isaiah, xi). Proverbs 10:7 exemplifies for Lowth what he means by "Parallel Terms":

"The memory (zeker) of the just (saddiq $)$ is a blessing;

" but the name $(\tilde{s e m})$ of the wicked $(\tilde{\text { resa }}$ im) shall rot.

(Isaiah, xix)

There are two sets of parallel terms here, one synonymous, "memory and name," which Lowth identifies explicitly, and the other antithetical, the just and the wicked (implied as the example is cited as a part of his discussion of antithetical parallelism). Attention to "par-

${ }^{67}$ E. L. Greenstein and M. O'Connor, "Parallelism" in PEPP, loc. 53381.

68 “Appositive Style," 1-32. Most intriguingly, Holmstedt argues that the interlineal relation of parallelistically juxtaposed lines is often appositional in nature. In fact, this is more readily apparent when syntax carries forward beyond the immediate grouping (couplet, triplet) level. Isaiah 10:6 is a good example, taken from Couey, Poetry of First Isaiah (115):

Against a godless nation I send him,

and against the people of my wrath I order him,

to spoil spoil and to plunder plunder,

and to trample them down like refuse in the streets.

And such appositional relations are on display on a much larger scale in narrative verse, such as that of ancient Ugarit. Many (most?) parallel lines in biblical Hebrew verse, however, are also simply juxtaposed, without explicit syntactic connection, and thus where the question of apposition does not arise.

${ }^{69}$ Greenstein, “How Does Parallelism Mean?” 44, n. 12; cf. Berlin, Dynamics, 18.

${ }^{70}$ Fabb's recent discrimination of parallelism's formal dimensions as consisting of three distinct elements, parallel members (lines), parallel terms, and the combination of the two by parallel pattern (What is Poetry? 142-43, 144), is ultimately rooted in Lowth's own threefold distinction between "Parallelism," "Parallel Lines," and "Parallel Terms." 
allel word pairs" increased significantly after the recovery of the Ugaritic texts, which revealed that these texts shared with the biblical poetic tradition sets of more or less fixed pairs of words that repeatedly occur in parallel lines. The first pair H. L. Ginsberg discusses gives a typical example of the phenomenon. ${ }^{71}$ ksp "silver" and hr.s "gold" appear more than two dozen times in parallel to one another in Ugaritic (e.g., "he casts silver [ksp] by the thousands / gold [hr.s] he casts by the ten thousands"; CAT 1.4.I.26-28). ${ }^{72}$ In the Bible, whenever hârus "gold" occurs, it is always paired in parallel with kesep "silver" (Zech 9:3; Ps 68:14; Prov 3:14; 8:10, 19; 16:16). ${ }^{73}$ Such conventional word pairs and phrases are one of the foremost formal features that frequently accompany parallelism in biblical poetry, as Greenstein in particular has emphasized. ${ }^{74}$ Parallel word pairs are common in much parallelistic oral verbal art as well. ${ }^{75} \mathrm{In}$ fact, James Fox grounds the primordial impulse toward parallelism in such parings: "the common tendency to resort to the pairing of words and phrases to provide emphasis, authority or significance to an expression of ideas." 76

\section{THE THREEFOLD SCHEMA}

When a scholar such as Berlin writes that "most contemporary scholars have abandoned the models of Lowth and his successors," what she has in view most particularly is Lowth's categorization of parallelism into three (semantic) "species": synonymous, antithetical, and synthetic (or constructive). The criticisms are myriad and well made. First, the schema is unnecessarily reductive. Even Lowth, at least initially, seems to have thought through these varieties more

71 Ginsberg was among the first to recognize this phenomenon. See H. L. Ginsberg and B. Maisler, "Semitized Hurrians in Syria and Palestine," JPOS 14 (1934): 248-40, n. 11; H. L. Ginsberg, "The Victory of the LandGod over the Sea God," JPOS 15 (1935): 327; "The Rebellion and Death of Ba'lu," Orientalia NS 5 (1936): 172.

72 U. Cassuto's compilations of word pairs in "Biblical and Canaanite Literature" and in "Parallel Words in Hebrew and Ugaritic" (1947) in Biblical and Oriental Studies (Jerusalem: Magnes, 1975 [1942-43]), 2: 43-45, 6068 , remain the seminal collections of such pairs; see also M. Dahood, "Hebrew-Ugaritc Parallel Pairs" in Ras Shamra Parallels, vol. 1, ed. L. Fisher (Rome: PBI, 1972), 234-35.

73 Ginsberg and Maisler, "Semitized Hurrians," 248, n. 15; Cassuto, "Biblical and Canaanite Literature," 51.

74 "Direct Discourse and Parallelism," 81. The literature on the topic is now expansive. For some representative treatments with references to later literature, see P. B. Yoder, "A-B Pairs and Oral Composition in Hebrew Poetry," VT 21 (1971): 470-89; O’Connor, Hebrew Verse Structure, 96-109; Y. Zakovitch, "Yes, There was an Israelite Epic in the Biblical Period," International Folklore Review 8 (1991): 20, 25, n. 16; Dobbs-Allsopp, On Biblical Poetry, 272-76.

${ }^{75}$ See the convenient surveys in Fox, Semantic Parallelism, esp. 19-90.

76 Semantic Parallelism, 3. 
heuristically. In Lecture IV, the three are only the most frequently used: "Of these three modes of ornament at least they make the most frequent use, namely, the amplification of the same ideas, the accumulation of others, and the opposition or antithesis of such as are contrary to each other"; and "the accumulation of others" is perhaps not yet the catchall category that it becomes in Lecture XIX ("all such that do not come within the two former classes"; Lectures, 1:100; 2:49). ${ }^{77}$ Even in Lecture XIX, parallelism's "variety" and "many gradations" are stressed, as noted earlier, and it is only "on the whole" that parallelism may be said "to consist of three species" (Lectures, 2:34). But the idea of three kinds of parallelism is unmistakably ramified by the time of the Preliminary Dissertation: "Parallel Lines may be reduced to Three sorts" (Isaiah, xi). Of course what Lowth counts as three kinds of parallelism others have numbered as many as eight. ${ }^{78}$ Instructively, C. Schoettgen, in a fifteen-page essay entitled "Exergasia Sacra" from 1733, ${ }^{79}$ anticipates Lowth's diagnosis of parallelism, though in terms of the rhetorical trope of exergasia ("the joining together of whole sententiae of the same significance") 80 and organized into ten "canons" or "rules" (with several illustrations for each). The latter generally comport well with Lowth's later "species" of parallelism: I-VII and X are treated by Lowth under the rubric of synonymous parallelism; VIII is antithetical parallelism; and IX is equivalent to Lowth's notion of synthetic parallelism (and equally weak). ${ }^{81}$ The different ways of categorizing what is essentially the same phenomena shows that there is nothing absolute about Lowth's threefold division. If anything, the latter, in particular, has had the effect of obscuring the subtleties that result from the inter-

77 Herder's early characterization of this final category, explicitly dependent on Lowth, is also much more heuristic in nature, "now a modification of the previous sense" (as cited in Smend, "Lowth in Germany," 207).

78 Pickett, Words and the Word, 110. And more recent typologies can number even more; e.g., Geller, Parallelism, 34-38 (twelve).

${ }^{79}$ Horae Hebraicae et Talmudicae (Jena, 1733), 1249-1263. For discussion and partial translations into English, see J. R. Lundbom, Jeremiah: A Study in Ancient Hebrew Rhetoric, 2nd ed (Winona Lake, IN: Eisenbrauns, 1997), 15563; Kugel, Idea, 266-73; cf. Baker, "Parallelism," 433. As the example of Schoettgen shows Lowth was not the first to recognize the phenomenon he called "parallelism." Indeed, Lowth himself cites the ideas of Azariah de Rossi (Isaiah, liii-lxvi). For other pre-Lowthian treatments of parallelism (however named), especially in Medieval Jewish scholarship, see Lausberg, Elemente der literarischen Rhetorik, \$336-40; A. Cooper, "Biblical Poetics: A Linguistic Approach" (Ph.D. diss.; Yale University, 1976), esp. Appendix II; Rehkopf, "Der 'Parallelismus' im NT," 51-57; Kugel, Idea, 96-286; A. Berlin, Biblical Poetry through Medieval Jewish Eyes (Bloomington: Indiana University Press, 1991); R. A. Harris, Discerning Parallelism: A Study in Northern French Medieval Jewish Exegesis, Brown Judaic Studies 341 (Providence, RI: Brown University Press, 2004).

80 Kugel, Idea, 267.

${ }^{81}$ Lundbom, Jeremiah, 162. 
action of parallelism's several formal dimensions and narrowing too much how these interactions are conceptualized. ${ }^{82}$ And while one prominent line of discussion about parallelism following Lowth focused on supplementing and/or redescribing Lowth's categories (e.g., complete, incomplete, numerical, impressionistic, repetitive, emblematic, internal, metathetic, climatic or staircase, chiastic, janus), what has become clear is that the varieties are endless and defy any neat classification scheme (however pragmatically handy certain descriptors may be for exposition)..$^{83}$

Lowth's individual "species" turn out upon inspection to be equally problematic. The "most frequent" kind of parallelism, ${ }^{84} \mathrm{ac}-$ cording to Lowth, is "synonymous parallelism," which he describes as that "which correspond one to another by expressing the same sense in different, but equivalent terms; when a Proposition is delivered, and is immediately repeated, in the whole or in part, the expression being varied, but the sense intirely, or nearly the same" (Isaiah, xi; cf. Lectures, 2:35). This conceptualization remains foundational for the field's understanding of parallelism. While Lowth clearly has in view both semantics ("sense") and grammatical form ("different, but equivalent terms"), the former is privileged in the denomination itself ("synonymous") and emphasized in the extended definition of the Preliminary Dissertation, viz. "the sense intirely, or nearly the same." And most treatments of parallelism after Lowth until the 1970s focused chiefly on semantic repetition, ${ }^{85}$ with many simply glossing parallelism, as James L. Kugel contends, as "saying the same thing twice." ${ }^{86}$ Exact synonymity—sameness without difference-does not exist. ${ }^{87}$ And it has been the difference(s) that parallelism activates that contemporary scholarship has exposed, revealing an infinite array of subtlety and nuance (in "literary effect" 88 that had previously been occluded or neutralized by the em-

\footnotetext{
${ }^{82}$ Esp. Kugel, Idea, 12, 15; cf. Berlin, Dynamics, 64.

83 Berlin, Dynamics, 64-65; cf. L. Alonso Schökel, A Manual of Hebrew Poetics, SubBib 11 (Rome: Pontificio Istituto Biblico, 1988), 57; O’Connor, Hebrew Verse Structure, 50; Geller, "Hebrew Prosody and Poetics, Biblical," loc. 33910. Similar conclusions and criticisms have been reached by scholars working in other traditions of oral-verbal art, where their analyses of parallelism inevitably begin with Lowth's schema; e.g., Fox, Semantic Parallelism, 31-32.

${ }^{84}$ In fact, it is far more common than all the other varieties combined; see O'Connor, Hebrew Verse Structure, 50.

${ }^{85}$ Greenstein, "How Does Parallelism Mean?" 44, n. 12.

${ }^{86} \mathrm{Idea}, 13$.

${ }^{87}$ O’Connor, Hebrew Verse Structure, 50-51; cf. J. Derrida, "Signature Event Context" in The Margins of Philosophy, trans. A. Bass (Chicago: University of Chicago Press, 1982), 307-30.

${ }^{88}$ Geller, Parallelism, 32. This ultimately follows the trajectory of R. Jakobson's thought, as he urged exploration of the "apportionment of invariants and variable" that is parallelism ("Grammatical Parallelism and its Russian Facet," Language 42 [1966]: 399-429, esp. 423; cf. Fox, Semantic Parallel-
} 
phasis on the same. Kugel and Robert Alter, among others, led the way in exploring the possibilities in parallelistic play beyond likeness, from emphasizing semantic coloring, focusing, intensification, ellipsis, and antithesis to elaborating incipient forms of narrativity. ${ }^{89}$ What has become of interest to biblical scholars is what takes place between the Lowthian parallel lines, or as a result of their combination, their being coupled in close adjacency. A not untypical example is provided by Gen 49:11:

$$
\begin{aligned}
& \text { kibbēs bayyayin lebuš̀ } \\
& \mathrm{V}+\mathrm{PP}+\mathrm{Obj}(+3 \mathrm{~ms} \mathrm{sf}) \\
& \text { he-washes in-wine his-garment } \\
& \text { bèdam- 'anabim sîtoh } \\
& \mathrm{PP}+\mathrm{Obj}(+3 \mathrm{~ms} \mathrm{sf}) \\
& \text { in-the-blood-of-grapes his-robe }
\end{aligned}
$$

The couplet is a part of a larger section of an old poem, the blessing of Jacob (Gen 49:2-27), in which Judah is lauded in royal imagery (vv. 8-12). The repeated syntactic frames in these lines are most exact $(\mathrm{V}+\mathrm{PP}+\mathrm{Obj}[+3 \mathrm{~ms} \mathrm{sf}] / / \mathrm{PP}+\mathrm{Obj}[+3 \mathrm{~ms} \mathrm{sf}])$, with gapping of the verb kibbes "he washes" in the second line. ${ }^{90}$ Washing "in wine" is an image of hyperbolic weal and superabundance. Wine itself already symbolizes superfluity (e.g., Song 1:2). Here, moreover, so productive are Judah's vineyards that the latter can wash, not in water with soap as normally (cf. Lev 14:8; 2 Kgs 18:17; Jer 2:22; Job 9:30), but in the excessive amounts of wine produced. The second line is a reformulation of this superlativeness - the "blood of grapes" appears in traditional parings with "wine" (e.g., Deut 32:14; CAT 1.4.IV.38) - that shifts the whole image, ${ }^{91}$ coloring the fantastic

ism, 31-33).

89 Alter, Art of Biblical Poetry, 1-38; Kugel, Idea, 1-58. Notably, both of these scholars stand out because of the more thoroughgoing literary focus of their work. Linguistics per se does not figure so prominently for them as for others of this generation. For a recent treatment of these issues, with nuance and sophistication (literarily and linguistically), see Couey, Poetry of First Isaiah, 71-91.

90 The longer prepositional phrase in the second line ("in-the-blood-ofgrapes") compensates for the gapping of the verb and in the process achieves the rough "balance of line length" that typifies parallelistic couplets in the Bible (cf. Greenstein, "Aspects of Biblical Poetry," 36, 39; "Hebrew Poetry, Biblical" in PEPP, loc. 33424; "Direct Discourse and Parallelism," 81).

91 As Geller notices of this word pair in particular, the repetitiveness that the conventional pairing of these terms implicates does not completely dissolve the metaphoricity of the phrase "blood of grapes" or how the latter colors the entire parallel relationship (Parallelism, 34). Generally, "an analysis that reduces lexical congruence to identity misrepresents" a critical dimension of parallel patterning (Fox, Semantic Parallelism, 32). 
washing with violent tonalities. The semantics of the phrase focalizes the crushing of the grapes (not the finished product; cf. Deut 32:14), which is itself a violent exercise. And not surprisingly, such treading gets used to metaphorize battle (e.g., Isa 62:2-3; Lam 1:15c), including most famously in the coronation imagery for a new Davidide in Isa 9:4 - the bath becomes bloody, a blood bath. The juxtaposed parallel frames coerce auditors into considering the two images together and give rise to a "new perception" in the process. ${ }^{92}$ The high esteem of wine and violent achievement in battle meld together to magnify the figure's royal trappings, epitomizing one version of the hyper-masculine image of the able Levantine ruler. ${ }^{93}$

Biblical poets turn out to be very much alive to the chances for dynamic interplay between parallel lines, in which, for example, "feelings get stronger, images sharper, actions more powerful or more extreme," 94 or as in Gen 49:11, shades of meaning get layered on. And yet the recurrence and redundancy, the matching that is the motor of this parallelistic play that can also open onto difference and newness, should not be forgotten. ${ }^{95}$ Certainly roughly similar (intentionally emphasizing the closely same) parallelisms do obviously occur (despite also always being riven by difference). ${ }^{96}$ The primacy of recurrence is rooted deeply in oral culture and the cognitive needs of oral discourse, which without benefit of mind-external back looping technology (e.g., writing) tends to "move ahead more slowly, keeping close to the focus of attention much of what it has already dealt with. Redundancy, repetition of the just-said, keeps both speaker and hearer surely on the track." 97 The logic governing parallelism is, at heart, a logic of repetition, or, as Lowth put it, of "correspondence" (Lectures, 2:34). ${ }^{98}$ That which is repeated is singular, its very iterability

92 See Alter, Art of Biblical Poetry, 16; cf. C. Westermann, Genesis 37-50, Continental Commentary, trans. J. J. Scullion (Minneapolis: Augsburg, 1986), 231.

${ }^{3}$ Cf. I. J. Winter, "The Body of the Able Ruler: Toward an Understanding of the Statues of Gudea," in Dumu- $e^{2}-d u b-b a-a$ : Studies in Honor of Ake W. Sjöberg, ed. H. Behrens, D. Loding, and M. T. Roth, Occasional Publications of the Samuel Noah Kramer Fund 11 (Philadelphia: University Museum, 1989), 573-83.

94 Art of Biblical Poetry, 23.

95 Note Holmstedt's emphasis on reformulation that allows for both recurrence and difference ("Appositive Style").

${ }^{6}$ Alter, Art of Biblical Poetry, 22; cf. D. Pardee, Ugaritic and Hebrew Parallelism: A Trial Cut ("nt I and Proverbs 2), VTSup 39 (Leiden: Brill, 1988), esp. 72-75, 169-70; W. G. E. Watson, Classical Hebrew Poetry: A Guide to its Techniques, JSOTSup 26 (Sheffield: Sheffield Academic Press, 1984), 133 34, 150, n. 1; Couey, Poetry of First Isaiah, 85-91.

${ }_{97} \mathrm{~W}$. Ong, Orality and Literacy: The Technologizing of the Word (London: Routledge, 1982), 40; cf. M. Jousse, Oral Style, trans. E. Sieneart and R. Whitaker (New York: Garland, 1990 [1925]), 95-107; R. Finnegan, Oral Poetry: Its Nature, Significance, and Social Context (Cambridge: Cambridge University Press, 1977), 130-33; Zumthor, Oral Poetry, 110-13.

${ }^{98}$ Recurrence and repetition are also accentuated in much of Jakobson's 
constituting an identity. ${ }^{99}$ And while parallelism in biblical poetry is operative at structural domains beyond the line, given the propensity in biblical verse for there to be "a certain relation between the composition of the Verses and the composition of the Sentences," it is not surprising that the prototypical entity of singularity (or identity) that parallelism picks out is the line: "the correspondence of one Verse, or Line, with another," says Lowth, "I call Parallelism" (Isaiah, $\mathrm{x}) .{ }^{100}$ Of course, the grouping of the singular lines into parallel patterns (sequences of similarity in form, meaning, or both) is equally constitutive of parallelism - absent such combinatory organization parallelism cannot be apprehended as such. The couplet is the most common frame for parallelism encountered in biblical poems, and indeed in oral verbal art generally. ${ }^{101}$ Although parallelism can also occur in threes, fours and fives, as Lowth well understood (Lectures, $2: 42-43),{ }^{102}$ which reifies the central force of the iteration of the singular in parallelism. ${ }^{103}$

"Antithetical parallelism" is the second species of parallelism described by Lowth: "when a thing is illustrated by its contrary being opposed to it. This is not confined to any particular form: for sentiments are opposed to sentiments, words to words, singulars to singulars, plurals to plurals, \&c" (Lectures, 2:45; cf. Isaiah, xix). Lowth's first example from Prov 27:6 is typical:

" The blows of a friend are faithful;

work; see esp. "Grammatical Parallelism," 399-429. However, he also emphasizes the importance of distinguishing between iteration and parallelism as they are not identical phenomena (esp. 423; cf. Fox, Semantic Parallelism, $31-3$.

99 The possibility of repeating is constitutive of identity, according to Derrida ("Signature Event Context," 315, 318). Though such "identity" is also riven by difference, the capability of occurring again, there being another, a second iteration by its very nature introduces an "essential dehiscence" (p. 326), and thus the identity so constituted is never quite identical with itself, not a "unity of self-identity" or a "pure singularity" (pp. 318, 326). And so the difference that Alter so creatively and wonderfully exploits in his analysis of the Bible's poetic parallelism is itself constitutive of the very intermittentness that lies at the heart of how parallelism means.

100 This is broadly characteristic of oral verbal art that is systematically or intermittently parallelistic, so Fabb, What is Poetry? 142 ("often the parallel member is a hemistich or line").

101 Jousse connects this to human bilateralism; see Oral Style, 95-100, 238, 239-40; cf. B. Antomarini, "The Acoustical Prehistory of Poetry," NLH 35 (2004): 363-65. More recently, Fabb emphasizes the role of working memory; see "Parallelism and Working Memory," 355-72.

102 Online grouping more generally in biblical poetry, see Dobbs-Allsopp, On Biblical Poetry, 74-84. The increased scale of these larger grouping patterns requires the contribution of long-term memory; see Fabb, "Parallelism and Working Memory."

103 Cf. O’Connor, "Parallelism," 878. 
" but the kisses of an enemy are treacherous. (Lectures, 2:45)

The contemporary critique here again is not so much on what Lowth picks out for analysis but how he conceptualizes it. As Kugel quips, it is "a distinction without a difference." 104 That is, the focus remains on semantics - contrast or opposition instead of likeness. It is "another way" for what comes afterwards "to pick up and complete" what precedes. ${ }^{105}$ Moreover, O'Connor points out that this variety of parallelism "largely occurs" in the wisdom literature of the Bible (especially Proverbs), making "it suspect as an independent category."'106

The last of the Lowthian categories is "Synthetic or Constructive parallelism," wherein "the sentences answer to each other, not by the iteration of the same image or sentiment, or the opposition of their contraries, but merely by the form of construction" (Lectures, $2: 48-49$; cf. Isaiah, xxi). The critique here is entirely different. If conceptualization and an over-emphasis on semantics are faulted in Lowth's characterizations of synonymous and antithetical parallelism, most contemporary scholars nonetheless agree that the underlying phenomena diagnosed are of issue, that Lowth (and his predecessors) had identified an important feature of biblical verse. The problem with the third category is phenomenological. As G. B. Gray observed, while Lowth's examples of synthetic parallelism "include, indeed, many couplets to which the term parallelism can with complete propriety be applied," there are other examples "in which no term in the second line is parallel to any term in the first, but in which the second line consists entirely of what is fresh and additional to the first; and in some of these examples the two lines are not even parallel to one another by the correspondence of similar grammatical terms." 107 In short, many of the lines categorized under the rubric of "synthetic parallelism" exhibit no parallelism whatsoever. The category becomes a kind of catchall: "all such as do not come within the former two classes" "may be referred" to this final class (Lectures, 2:49). Lowth's mistake is in pressing the idea of parallelism too far, in trying to make it account for the interrelations of all sets of lines in biblical verse. The impetus for this press arises from Lowth's strong attraction to formalism and his conviction that "the artificial conformation of the sentences," which is most observable where parallelism prevails, was "a necessary concomitant of metrical composition"- "the only one indeed," Lowth emphasizes, "which is now apparent" (Lectures, 2:11; cf. 53). ${ }^{108}$ And given that prophetic

${ }^{104}$ Idea, 13; cf. O’Connor, "Afterword," 640.

${ }^{105}$ Idea, 13.

106 "Parallelism," 878.

107 G. B. Gray, The Forms of Hebrew Poetry (London: Hodder and Stoughton, 1915), 49, 50.

108 Recall that Lowth's first description of the "conformation of the sentences" and parallelism is in Lecture III, where he contends that biblical Hebrew verse is metrical even though most signs of that metricality are no 
verse is a privileged site for Lowth's explication of parallelism, it may be that the "argumentative" nature of this verse with so many sets of lines not readily conceptualized in terms of synonymity or anonymity induced Lowth to stretch his idea of parallelism too far. ${ }^{109}$ Regardless of the impetus, to allow parallelism to cover every possible interlinear relationship in biblical verse, even where no ostensible signs of parallelism exist, is to make the idea of parallelism itself untenable, "undeniable."110 Rather, as Gray contends, "the study of parallelism must lead ... to the conclusion that parallelism is but one of the forms of Hebrew poetry." 111 Parallelism simply is not everywhere in the biblical corpus. Conservatively estimated, as much as a third of the corpus is composed of non-parallelistic lines. ${ }^{112}$ David Norton, a non-biblicist, acutely draws out the logical implication of the presence of non-parallelistic lines that has all too often been missed even by specialists: "if there are unparallel lines, and parts of the poetry where parallelism is not apparent, it would seem that parallelism is not to be found everywhere in the poetry: consequently parallelism cannot be taken as the general system it is often thought of as being." 113 This is not to underestimate the importance of parallelism when it occurs, when it recurs sufficiently enough and within limits of variability such that auditorial expectations of recurrence are actively elicited. Rather it is to observe that biblical poems are only rarely systematically parallelistic. More frequently, patterns of parallelism are prominent, though almost always mixed in with non-

longer apparent. Cf. Kugel, Idea, 73-74; Petersen and Richards, Interpreting Hebrew Poetry, 22.

109 Cf. Skornik, "Robert Lowth on the Species of Prophetic Poetry."

110 O'Connor, Hebrew Verse Structure, 51. Geller's judgement is similarly blunt: the category is "essentially useless" (Parallelism, 31; see also Appendix B). Cf. Greenstein, "How Does Parallelism Mean?" 45; Kugel, Idea, 57; Alter, Art of Biblical Poetry, 19. I have the impression from Fox's surveys in Semantic Parallelism that scholars working on parallelism in other (oral) poetic traditions have not perceived this weakness in Lowth's thinking as acutely as have biblical scholars.

${ }^{111}$ Forms of Hebrew Poetry, 123; cf. Driver, Introduction, 362; R. Culley, Oral Formulaic Language in the Biblical Psalms (Toronto: University of Toronto Press, 1967), 119; Kugel, Idea, 74; Watson, Classical Hebrew Poetry, 118 and n. 8; Petersen and Richards, Interpreting Hebrew Poetry, 27.

112 Esp. O’Connor, Hebrew Verse Structure, 409; see Geller, Parallelism, 6, 30, 295, 379; T. Collins, Line-Forms in Hebrew Poetry: A Grammatical Approach to the Stylistic Study of the Hebrew Prophets (Rome: Biblical Institute, 1978), 89; Greenstein, "How Does Parallelism Mean?" 45-46; Watson, Classical Hebrew Poetry, 332-36; J. F. Hobbins, "Regularities in Ancient Hebrew Verse: A New Descriptive Model," ZAW 119 (2007): 573-76; Couey, Poetry of First Isaiah, 29, 38-39; Dobbs-Allsopp, On Biblical Poetry, 45-48, 137, 138-39, 204, 329, 330-31, 336, 507, n. 22.

113 A History of the English Bible as Literature (Cambridge: Cambridge University Press, 2004), 227. 
parallel lines. And there are even occasions, such as in Lamentations $1-4$, where parallelism occurs but is not prominent. ${ }^{114}$

\section{PARALLELISM, ORALITY, AND RHYTHM}

Another post-Lowthian emphasis in the study of parallelism is the recognition that this kind of formal ornamentation is a rather common feature of traditional oral performative art generally. So Robert B. Coote writes: "It is in fact a nearly universal characteristic of traditional language and needs no special explanation." ${ }^{115}$ Crucially, impetus for querying the models of oral communication that inform biblical poetic rhetoric (including the pervasive use of parallelism) dates back to Lowth, whom Scott Harshbarger credits as the most "influential" eighteenth-century framer of an embryonic form of "rhetorical anthropology" with just such interests. ${ }^{116}$ Lowth reveals the underlying orality that informs so much biblical poetry in a comment right before his treatment of Lamech's song (Gen 4:23-24) discussed earlier: "The only mode of instruction, indeed, adapted to human nature in an uncivilized state, when the knowledge of letters was very little, if at all diffused, must be that which is calculated to captivate the ear and the passions, which assists the memory, which is not to be delivered into the hand, but infused into the mind and heart" (Lectures, 1:88). Elsewhere he points to Deut 31:19, 21 and the "song of Moses" that follows (Deuteronomy 32) as one place where this oral dimension is made explicit (Lectures, 2:19). ${ }^{117}$ In this respect Israelite and Judahite culture was not unlike that of early Greece, where "Poetry was of singular utility, since, before any characters expressive of sounds were invented, at least before they were commonly received, and applied to general use, it seems to have afforded

\footnotetext{
114 For an extended treatment of "enjambment" (which at the surface of the poem provides the most prominent alternative to parallelistic lines (cf. Alter, Art of Biblical Poetry, 19) in Lamentations, see F. W. Dobbs-Allsopp, "The Enjambing Line in Lamentations: A Taxonomy (Part I)," $Z A W$ 113 (2001): 219-39; and "The Effects of Enjambment in Lamentations (Part 2)," ZAW 113 (2001): 370-85. Greenstein's appeal to deep structure analysis results in less widespread sets of enjambed lines.

115 "The Application of Oral Theory to Biblical Hebrew Literature," Semeia 5 (1976): 59-60; cf. Jousse, Oral Syle, 95; Finnegan, Oral Poetry, 98-109; R. Bauman, Verbal Art as Performance (Long Grove, IL: Waveland, 1977), 18-19; Zumthor, Oral Poetry, 111, 137; J. M. Foley, How to Read an Oral Poem (Urbana: University of Illinois Press, 2002), 89-90; R. D. Miller, Oral Tradition in Ancient Israel (Eugene, OR: Cascade, 2011), 72; Greenstein and O'Connor, "Parallelism," loc. 53479; Dobbs-Allsopp, On Biblical Poetry, esp. 269-72.

116 “Oral Dimension," 199-214, here at 200; cf. Engell, "Robert Lowth," 130. Harshbarger is among those interested in Lowth's broader intellectual significance-here the focus is Lowth's influence on Romanticism.

117 Cf. Dobbs-Allsopp, On Biblical Poetry, 266, 268, 277-78, 283, 294, 305, 315-16.
} 
the only means of preserving the rude science of the early times; and, in this respect, to have rendered the want of letters more tolerable" (Lectures, 1:82; see 80-88). In regard to parallelism specifically, Lowth locates the form's proximate origin in the call and response ("alternate song") of communal group singing, "thus one choir sings, 'Saul has smote his thousands;' the other answering, 'And David his ten thousands"' (1 Sam 18:7; Lectures, 2:27-29). For Lowth this explains why so many "distichs should in some measure consist of versicles or parallelisms corresponding to each other" (Lectures, 2:32), although he also allows that the pattern could be "easily extended ... into the other species of poetry" (Lectures, 2:33). While such antiphonal singing will have been a part of the song culture of ancient Israel and Judah, this does not offer the tight, genealogical explanation of parallelism that Lowth imagines. Herder, for example, sharply disputes this idea, maintaining it to be "contrary to all probability, indeed contrary to the history of all poetry" and preferring instead to imagine ancient Hebrew poetry emerging initially as a form of "country music, of youthful shouts of joy and pleasure, the dances and songs of the people." 118 Still, Lowth's awareness of the rootedness of biblical Hebrew poetry and its parallelistic structures in orality is an important dimension of his diagnosis, albeit one more impactful on ensuing poetic practice (e.g., Blair, James Fenimore Cooper, Macpherson, Wordsworth-all develop interests in oral qualities of poetic language traceable back to Lowth) than on later biblical scholarship where this aspect of Lowth's thinking has been mostly missed. To wit, Marcel Jousse writes, "Lowth could not have realized...the enormous psychological importance of this phenomenon." 119 And as Jousse's own work illustrates, Lowth's influence on the diagnosis of parallelism in oral verbal art is immense. ${ }^{120}$

Because of Lowth's intellectual demeanor-especially his nondogmatism and nimbleness of mind-and his acute sensitivity to historical contingency, he was able to stretch received understandings in order to accommodate (and thereby disclose) a prosodic and rhetorical tradition that proved quite distinct from those of the known Greco-Roman worlds. ${ }^{121}$ For example, whereas Lowth deplores

118 As cited in Smend, "Lowth in Germany," 207 (the manuscript being quoted is from 1769). Herder, too, understood the prominence of antiphonal singing in ancient Israel and Judah; see J. G. Herder, Selected Early Works (1764-1767), ed. E. A. Menze and K. Menges, trans. E. A. Menze with M. Palma (University Park: Penn State University Press, 1992), 184. On group singing in particular, see Dobbs-Allsopp, On Biblical Poetry, 196, $289,193,479$, n. 54; and for my own understanding of the interface of orality, literacy, and textuality at the site of biblical poetry, see in detail pp. 233325 (parallelism is especially in focus on pp. 269-72).

119 The Oral Style, trans. E. Sienaerta and R. Whitaker (New York: Garland, 1990 [1925]), 95.

${ }^{120}$ For recent surveys, see esp. Fox, Semantic Parallelism, chs. 2-3; and the entire issue of Oral Tradition 31 (2017).

121 Harshbarger, "Oral Dimension," 201; cf. Engell, "Robert Lowth," 
"those forms of tropes and figures, which the teachers of rhetoric have pompously (not to say uselessly) heaped together," nevertheless he still uses them, albeit "not as freely as we might, but as much only as shall appear absolutely necessary" (Lectures, 1:75-76). I remarked earlier on how Lowth expands and generalizes what he means by "member" and "period." Still other concepts derived from the same classical rhetorical tradition he can employ more straightforwardly (e.g., "invention," "arrangement," "style," "exordium"). ${ }^{122}$ The question of meter is handled with the same flexibility and cognizance of cultural particularity - "the peculiar marks and characters of the Hebrew poetry" (Lectures, 1:76). Lowth is unable to conceptualize poetry outside of a metrical framework. Even while he stresses that "nothing certain can be defined concerning the metre of the particular verses" of Hebrew poetry (Lectures, 1:68), he continues to think it "not improbable that some regard was also paid to the numbers and feet" (Lectures, 2:54). Still, he trusts his new kind of empirically grounded close reading, ${ }^{123}$ noticing the "measured cadence" effected by the rough regularity of the "conformation of the sentences" and the parallelistic patterning it sponsors (Lectures, 1:68-69). In fact, this "conformation of the sentences," he says later, "has always appeared to me a necessary concomitant of metrical composition" (Lectures, 2:11; cf. 1:99; 2:53-54). In the end, this "measured cadence" ultimately resists strict numerical quantification. And yet in its very articulation Lowth may be seen stretching the received ideas about metricality; indeed, as Engell astutely observes, Lowth "actually ends up providing a new, different kind of poetic original ... [that] could not be reduced, despite his own efforts, to set meters." 124 Lowth cites Cicero as authorization for this expanded notion of "metrical cadence":

[1] certain forms of expression there exists such a degree of conciseness, that a sort of metrical arrangement follows of course. For, when words or sentences directly correspond, or when contraries are opposed exactly to each other, or even when words of a similar sound run parallel, the composition will in general have a metrical cadence. (Lectures, 1:101-102)

This permits Lowth to conclude that "the frequent or rather perpetual splendour of the sentences, and the accurate recurrence of the clauses," though "in any other language would appear a superfluous and tiresome repetition," in Hebrew poetry "always reduces a

$119-20,128-30$.

122 "Oral Dimension," 202.

123 Engell observes that Lowth's Life of William of Wykeham (1758) is "one of the first English books to employ evidence ordered and assessed by modern principles and scholarly, historical documentation" ("Robert Lowth," 126).

124 "Robert Lowth," 123. 
composition to a kind of metrical form" (Lectures, 1:101). ${ }^{125}$ This changes how poetry is imagined in the West (especially in English language poetry) and makes possible "the unrhymed verse without strict metrical scansion" of "Blake, Smart, Cowper, Macpherson, and Whitman"- and eventually of free verse more generally. ${ }^{126}$

Herder, who opens The Spirit of Hebrew Poetry by lauding "the beautiful and justly celebrated work of Bp. Lowth," 127 almost immediately begins to loosen up how he [Herder] conceptualizes Hebrew poetic prosody, using the idea of a "rhythm" characterized "by declamation too forceful to be confined by a meter." 128 Nevertheless, biblical scholarship more generally takes longer to absorb fully the consequences of Lowth's expanded sensibility about what counts as metrical. Not until Benjamin Hrushovski's [Harshav's] seminal "On Free Rhythms in Modern Poetry" - which aims to account prosodically for the rhythmic achievements of the kind of not-strictly-metrical verse inspired by Lowth - is a conceptual framework articulated for understanding the rhythm of biblical poetry beyond the positing of strict numerical regularity. ${ }^{129}$ Echoing (ultimately) Lowth, Hrushovski observes that "no exact regularity of any kind has been found" and thus by definition "the poetry of the Hebrew Bible" forms "a 'natural' free-rhythmic system." 130 A free rhythm is "a rhythm based on a cluster of changing principles." 131 Parallelism, in all of its variability, offers one set of parameters that may contribute to a given biblical poem's overall rhythm. For example, the recurrence of (variable) parallel patterns itself results in perhaps the most pronounced rhythmic effect of biblical verse. In poems composed predominantly of parallelistic couplets and triplets the forward movement of the

125 Cf. Harshbarger "Oral Dimension,” 203-4.

126 Engell, "Robert Lowth," 123-25, 131; “Other Classic," 355-58. For Lowth's importance for Goethe, see Smend, "Lowth in Germany," 204 205.

127 J. G. Herder, The Spirit of Hebrew Poetry, 2 vols (Burlington: Edward Smith, 1833), 1:13. For Herder's reception of Lowth, see Smend, "Lowth in Germany," 204-209.

${ }^{128}$ Herder, Selected Early Works, 184; cf. 41-42, 71, 141-42.

${ }^{129}$ In Style in Language, ed. T. Sebeok (New York: Technology Press of the Massachusetts Institute of Technology and John Wiley \& Sons, Inc., 1960), 173-90, esp. 189-90; cf. "Prosody, Hebrew" in EncJud, vol. 13 (1971-72): 1200-1203; and "Note on the Systems of Hebrew Versification" in The Penguin Book of Hebrew Verse, ed. T. Carmi (New York: Penguin Books, 1982), 57-72. Greenstein also emphasizes the importance of the "quasimetrical balancing of line length" as an "agent of parallelism" ("Aspects of Biblical Poetry," 39). The rough balance of line length (following Lowth) and the tendency to compensate for deleted or gapped elements are for Greenstein two indirect signs of the rhythmicity that informs and shapes sets of parallel lines in biblical verse (37). See now F. W. Dobbs-Allsopp, "The Free Rhythms of Biblical Hebrew Poetry" in On Biblical Poetry, 95177.

130 “Prosody, Hebrew," 1200; “On Free Rhythms,” 189.

131 Hrushovski, “Prosody, Hebrew," 1200. 
rhythm is periodically checked by moments of felt-stasis as the balancing and repetition (with difference) at the heart of parallelismone propositional gesture instinctively triggering another of like form and meaning 132 —enact their bilateral pulse. Such poems have a deliberative, ambling pace as their basic rhythmic ground: one step forward, iteration; another step and another iteration, and sometimes two (in triplets); a further step accompanied by a further iteration; and so on. ${ }^{133}$ There may be no better description and illustration of this rhythm than that provided by John Hollander in his delightful imitation of it:

The verse of the Hebrew Bible is strange; the meter of Psalms and Proverbs perplexes.

It is not a matter of number, no counting of beats or syllables.

Its song is a music of matching, its rhythm a kind of paralleling.

One half-line makes an assertion; the other part paraphrases it; sometimes a third part will vary it. ${ }^{134}$

Not only does this effectively catch the rhythmic feel of so much biblical verse, Hollander's emphasizing of the rhythmic consequences of parallelism makes its own critical contribution to the understanding of biblical verse. ${ }^{135}$ And in doing so Hollander ultimately follows Lowth, for whom, as Engell explains, the meter of Hebrew verse was indeed perplexing, appearing to have "nothing to do with syllable, stress, or quantity in their usual senses, but rather with recurring patterns of syntactic and grammatical units, with couplings of phrase that repeat, amplify, or specify meaning in strongly rhythmical patterns."136

It merits stressing, in closing, that as Lowth was stretching received ideas of metricality such that they might accommodate the "measured cadence" of biblical poetry's free(er) rhythms, simultaneously he elucidated the corresponding play of parallelism that so of-

132 Translated into O’Connor's syntactic vocabulary, for example: “One line of given constituent or unit structure is followed by one or more of identical structure" (Hebrew Verse Structure, 391).

133 Cf. Alonso Schökel, Manual, 48. Also compare J. M. Foley’s related characterization of the rhythmic pulse of parallelism in so much orally performed South Slavic epic verse (How to Read an Oral Poem [Urbana: University of Illinois Press, 2002], 89).

134 Rhyme's Reason: A Guide to English Verse, enlarged ed. (New Haven: Yale University Press, 1989), 26; cf. Dobbs-Allsopp, On Biblical Poetry, 143 49 .

135 Parallelism now features prominently in many accounts of free verse rhythm: e.g., Smith, Poetic Closure, 84-92; C. O. Hartman, Free Verse: An Essay on Prosody (Evanston, IL: Northwestern University Press, 1980), 121-22; D. Attridge, Poetic Rhythm: An Introduction (Cambridge: Cambridge University Press, 1995), 169-70; G. B. Cooper, Mysterious Music: Rhythm and Free Verse (Stanford: Stanford University Press, 1998), 99-101.

136 "Robert Lowth," 131. 
ten animates the "conformation of the sentences" in this traditionthat bit of form Lowth thought "a necessary concomitant of metrical composition" (Lectures, 2:11) — "as if" it were itself "a kind of rule or measure" (Lectures, 2:34). Lowth's characteristic hedging here ("as if," "a kind of") fissures his own impulse toward systematicity. Yet whether systematic, pervasive, or intermittent this diagnosis of parallelism as poetic "ornament" (not unlike meter, rhyme, alliteration) is also part of how Lowth changes the modern perception of poetry and poetic practice. After Lowth poets-Christopher Smart, Edgar Allan Poe, Walt Whitman, Gerard Manley Hopkins-explore the dynamics of parallelism in their own verse and scholars, whether of past (Hebrew Bible, Ugaritic) or living (Rotenese, Kuna, Nahuatl) poetic traditions, become alert to the prospect of parallel form in the poetry they study. If phenomenologically parallelism was recognized before Lowth, it was Lowth's recognition of parallelism that nevertheless bequeathed the phenomenon to the modern world, for the work and study of poetry.

Parallelism, since Lowth's celebrated analysis in the middle of the eighteenth century, is the best-known characteristic of (much) biblical poetry, and, indeed, since the early 1990s, parallelism is now also the best understood feature of biblical poetry. Its many varieties and common tendencies, its basic mechanisms and key formal parameters (lines, terms, patterns), have been well researched, catalogued, and exemplified. If parallelism per se cannot be constitutive of biblical poetry-since there is a substantial amount of non-parallelistic lines in the biblical Hebrew poetic corpus-there is no denying its significance when present. The keen-ness of Lowth's generative insight continues to redound to this day- "this," as Herder long ago observed, "no one who has read the psalms, the prophets and Job can deny." 137

137 As cited in Smend, "Lowth in Germany," 207 (the observation dates from 1769). 
Fig. 1 Robert Lowth (1710-87). From an engraving of the original painting by L. E. Pine. (Wikimedia Commons, Public Domain).

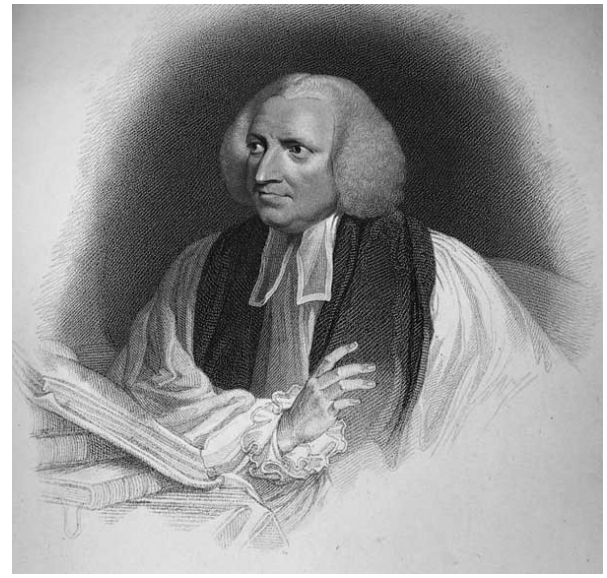

Fig. 2 R. Lowth, De Sacra Poesi Hebraeorum Praelectiones Academicae Oxonï Habitae (London: Clarendon, 1753), 39. Shows Lowth's lineated rendering of the Hebrew of Genesis 4:23-24, which was set in a running format by the Masoretes.

PRELIV. IV. HE B R \& O R U M.

genus populorum rudium et indoctorum, quibus aut nulla omnino aut minime pervagata erat literarum cognitio, utilitati accommodatum erat, quod aures animofque capturum, et memoriæ firmiter inhæafurum effet; quod non tradendum effet manibus, fed mentibus infundendum. Eodem modo apud Hebræos etiam fe rem habuiffe, ufumque Poeticæ cum valde antiquum, tum mature fuiffe communem et pervagatum, ut ex rei natura verifimile eft, ita clare etiam apparet ex reliquiis et veftigiis quibufdam dietionis poetice, qux in feriptis Mofaicis extant. Primum quod ibi occurrit hujus rei exemplum remotiffimæe atque intimx eft vetuftatis, Lamechi ad Uxores effatum, eo quidem obfcuriffimum, quod, qua occafione effet editum, omnino reticetur; catera autem, aptam verborum conftructionem, concinnam totius periodi in tria difticha diftributionem, fententias in fingulis diftichis binas parallelas, alteramque alteri quafi recinentes; ifthac, inquam, fi fpectetis, agnofcetis, credo, primævi carminis clariffimum fpecimen : 1

ערה וצלה שמע קולי,

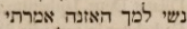

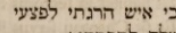

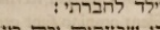

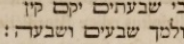

"Hadah et Sillah, audite vocem meam;

" Uxores Lamechi, aufcultate eloquium meum:

"Quod virum occidi in vulnus meum,

"Et puerum in livorem meum :

"Quia feptempliciter vindicabitur Cain,

" Et Lamech feptuagefies fepties.

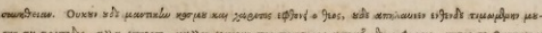

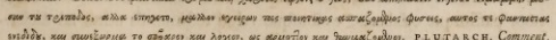

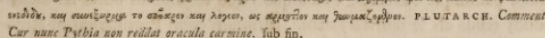

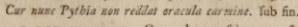
I osv. 1v, 23, 24. Cum plane neffiam qque fit hujus loci featentia, contentus fum fubjun. 